Prepared in cooperation with Blaine County, City of Hailey, City of Ketchum, The Nature Conservancy, City of Sun Valley, Sun Valley Water and Sewer District, Blaine Soil Conservation District, and the City of Bellevue

\title{
Quality of Groundwater and Surface Water, Wood River Valley, South-Central Idaho, July and August 2012
}

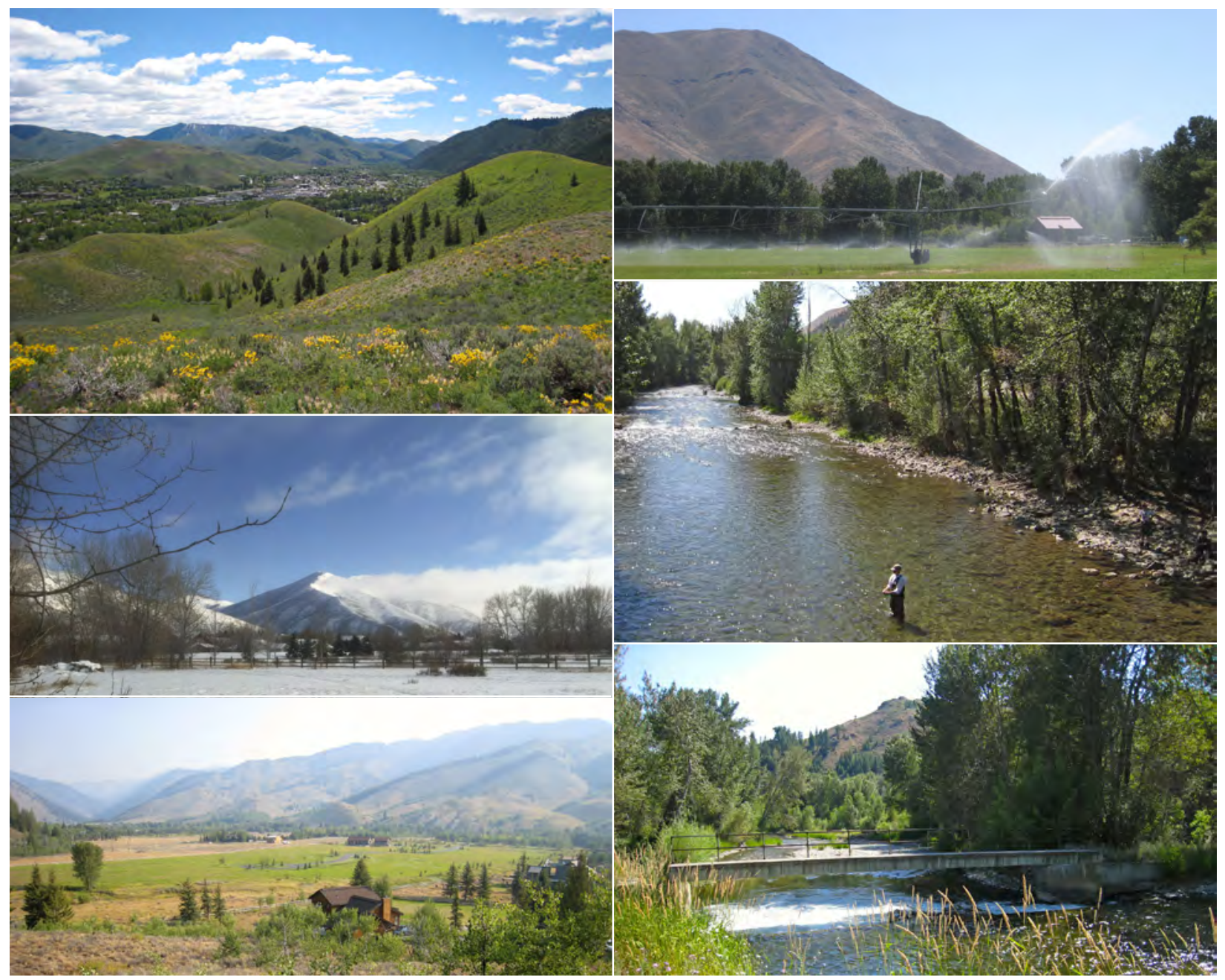

Scientific Investigations Report 2013-5163 


\section{Cover:}

Top left: Ketchum, view to southeast from Adams Gulch, June 8, 2008.

Middle left: Mouth of Slaughterhouse Gulch, view to southeast from Chantrelle subdivision, Bellevue, December 31, 2012.

Bottom left: Mouth of Chocolate Gulch, view to northeast from Chocolate Gulch, August 20, 2012.

Top right: Center-pivot irrigation west of Bellevue, view to east from Lower Broadford Road, August 10, 2013.

Middle right: Big Wood River west of Hailey, view to south from Croy Creek Road, August 10, 2012.

Bottom right: Hiawatha Canal diversion structure on the Big Wood River south of Greenhorn Gulch, view to south from Starweather subdivision, August 2, 2012.

All photographs by James R. Bartolino, U.S. Geological Survey. 


\section{Quality of Groundwater and Surface Water, Wood River Valley, South-Central Idaho, July and August 2012}

By Candice B. Hopkins and James R. Bartolino

Prepared in cooperation with Blaine County, City of Hailey, City of Ketchum, The Nature Conservancy, City of Sun Valley, Sun Valley Water and Sewer District, Blaine Soil Conservation District, and the City of Bellevue

Scientific Investigations Report 2013-5163 


\title{
U.S. Department of the Interior SALLY JEWELL, Secretary
}

\section{U.S. Geological Survey Suzette M. Kimball, Acting Director}

\author{
U.S. Geological Survey, Reston, Virginia: 2013
}

For more information on the USGS - the Federal source for science about the Earth, its natural and living resources, natural hazards, and the environment, visit http://www.usgs.gov or call 1-888-ASK-USGS.

For an overview of USGS information products, including maps, imagery, and publications, visit http://www.usgs.gov/pubprod

To order this and other USGS information products, visit http://store.usgs.gov

Any use of trade, firm, or product names is for descriptive purposes only and does not imply endorsement by the U.S. Government.

Although this information product, for the most part, is in the public domain, it also may contain copyrighted materials as noted in the text. Permission to reproduce copyrighted items must be secured from the copyright owner.

Suggested citation:

Hopkins, C.B., and Bartolino, J.R., 2013, Quality of groundwater and surface water, Wood River Valley, south-central Idaho, July and August 2012: U.S. Geological Survey Scientific Investigations Report 2013-5163, 32 p., http://pubs. usgs.gov/sir/2013/5163. 


\section{Contents}

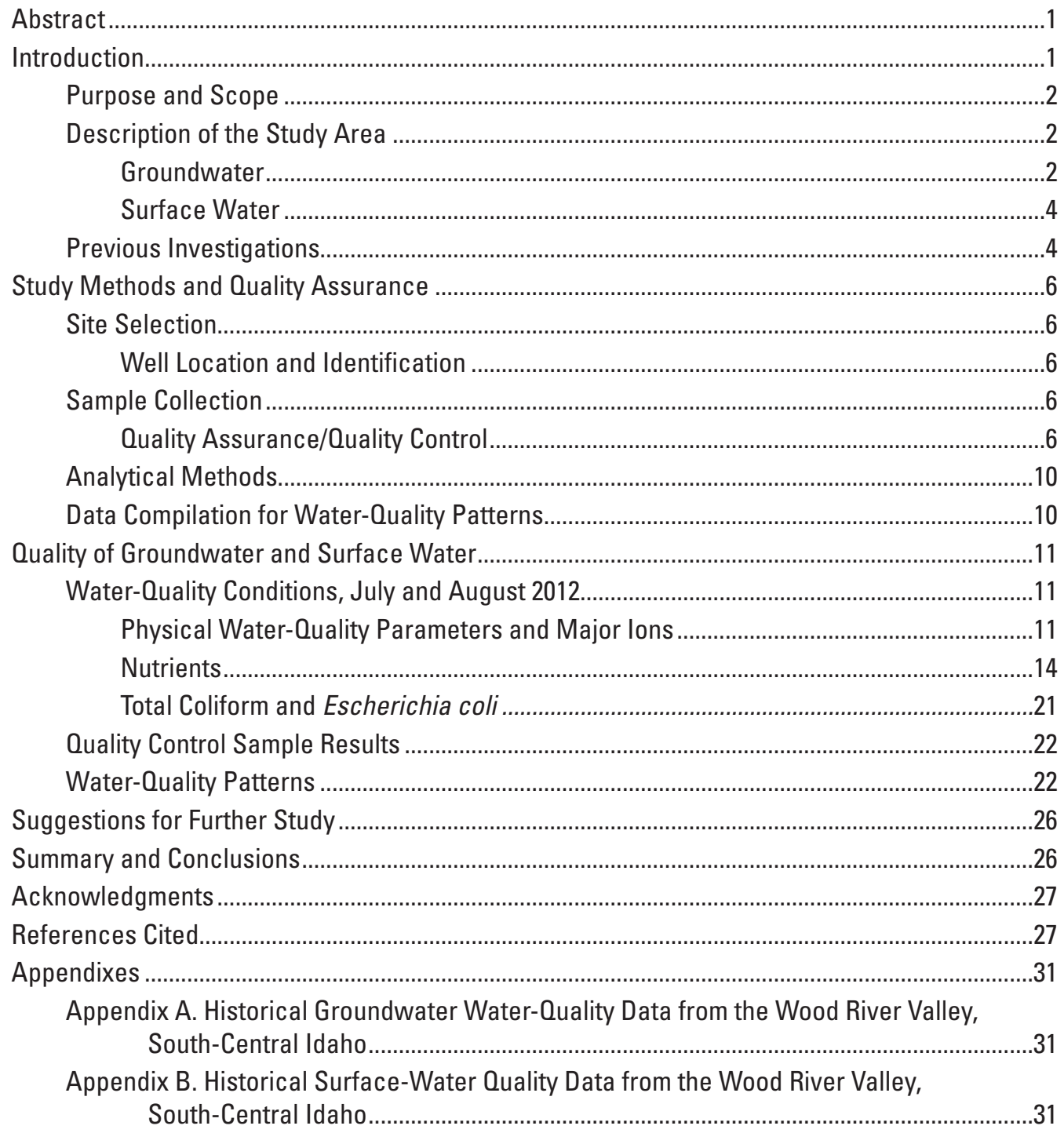




\section{Figures}

1. Map showing locations of communities, selected U.S. Geological Survey streamgaging stations, and other features, Wood River Valley, south-central Idaho.

2. Map showing groundwater and surface-water quality sites sampled in the Wood River Valley, Idaho, July and August 2012..

3. Diagram showing well-numbering system used in Idaho by the U.S. Geological Survey to designate a site name.

4. Boxplots showing total dissolved solids, magnesium, sulfate, and fluoride concentrations in groundwater and surface-water samples, Wood River Valley, south-central Idaho, July and August 2012.

5. Trilinear diagram showing relative composition of major ions in groundwater and surface-water samples, Wood River Valley, south-central Idaho, July and August 2012.

6. Boxplots showing boron, chloride, and nitrate plus nitrate as nitrogen concentrations in groundwater and surface-water samples, Wood River Valley, south-central Idaho, July and August 2012.

7. Graph showing boron and nitrate plus nitrite as nitrogen concentrations in groundwater and surface water, Wood River Valley, south-central Idaho, July and August 2012

8. Map showing concentrations of nitrate plus nitrite as nitrogen in groundwater and surface-water samples from the Wood River Valley, south-central Idaho, July and August 2012

9. Graph showing E. coli and nitrate plus nitrate concentrations in groundwater and surface-water samples, Wood River Valley, south-central Idaho, July and August 2012...

10. Graphs showing temporal variability in nitrate and chloride concentrations in water from six wells in the Wood River Valley, south-central Idaho

\section{Tables}

1. Site information, alternate names, and location information for groundwater and surface-water sampling sites in the Wood River Valley, south-central Idaho, July and August 2012

2. U.S. Environmental Protection Agency water-quality standards for drinking water for selected constituents analyzed in samples collected from groundwater and surface water in the Wood River Valley, south-central Idaho, July and August 2012

3. Physical parameters of groundwater and surface-water samples, Wood River Valley, south-central Idaho, July and August 2012.

4. Major ion and selected trace element concentrations in groundwater and surface-water samples, Wood River Valley, south-central Idaho, July and August 2012.

5. Nutrient concentrations and bacteria counts in groundwater and surface-water samples, Wood River Valley, south-central Idaho, July and August 2012.

6. Laboratory results for replicate and blank groundwater and surface-water samples, Wood River Valley, south-central Idaho, July and August 2012 


\section{Conversion Factors and Datums}

Conversion Factors

\begin{tabular}{lcl}
\hline \multicolumn{1}{c}{ Multiply } & By & \multicolumn{1}{c}{ To obtain } \\
\hline foot (ft) & Length & \\
mile (mi) & 0.3048 & meter $(\mathrm{m})$ \\
& 1.609 & kilometer $(\mathrm{km})$ \\
\hline section (640 acres or 1 square mile) & Area & \\
square mile (mi2) & 259.0 & square hectometer $\left(\mathrm{hm}^{2}\right)$ \\
\hline & 2.590 & square kilometer $\left(\mathrm{km}^{2}\right)$ \\
\hline cubic foot per second $\left(\mathrm{ft}^{3} / \mathrm{s}\right)$ & Flow rate & \\
\hline
\end{tabular}

Temperature in degrees Celsius $\left({ }^{\circ} \mathrm{C}\right)$ may be converted to degrees Fahrenheit $\left({ }^{\circ} \mathrm{F}\right)$ as follows:

$$
{ }^{\circ} \mathrm{F}=\left(1.8 \times^{\circ} \mathrm{C}\right)+32 \text {. }
$$

Specific conductance is given in microsiemens per centimeter at 25 degrees Celsius $(\mu \mathrm{S} / \mathrm{cm}$ at $\left.25^{\circ} \mathrm{C}\right)$.

Concentrations of chemical constituents in water are given either in milligrams per liter (mg/L) or micrograms per liter $(\mu \mathrm{g} / \mathrm{L})$.

Datums

Vertical coordinate information is referenced to the National Geodetic Vertical Datum of 1929 (NGVD29).

Horizontal coordinate information is referenced to the North American Datum of 1927 (NAD 27). Altitude, as used in this report, refers to distance above the vertical datum. 
This page intentionally left blank. 


\title{
Quality of Groundwater and Surface Water, Wood River Valley, South-Central Idaho, July and August 2012
}

\author{
By Candice B. Hopkins and James R. Bartolino
}

\section{Abstract}

Residents and resource managers of the Wood River Valley of south-central Idaho are concerned about the effects that population growth might have on the quality of groundwater and surface water. As part of a multi-phase assessment of the groundwater resources in the study area, the U.S. Geological Survey evaluated the quality of water at 45 groundwater and 5 surface-water sites throughout the Wood River Valley during July and August 2012. Water samples were analyzed for field parameters (temperature, $\mathrm{pH}$, specific conductance, dissolved oxygen, and alkalinity), major ions, boron, iron, manganese, nutrients, and Escherichia coli (E coli) and total coliform bacteria.

This study was conducted to determine baseline water quality throughout the Wood River Valley, with special emphasis on nutrient concentrations. Water quality in most samples collected did not exceed U.S. Environmental Protection Agency standards for drinking water. E. coli bacteria, used as indicators of water quality, were detected in all five surface-water samples and in two groundwater samples collected. Some analytes have aesthetic-based recommended drinking water standards; one groundwater sample exceeded recommended iron concentrations. Nitrate plus nitrite concentrations varied, but tended to be higher near population centers and in agricultural areas than in tributaries and less populated areas. These higher nitrate plus nitrite concentrations were not correlated with boron concentrations or the presence of bacteria, common indicators of sources of nutrients to water. None of the samples collected exceeded drinking-water standards for nitrate or nitrite.

The concentration of total dissolved solids varied considerably in the waters sampled; however a calciummagnesium-bicarbonate water type was dominant (43 out of 50 samples) in both the groundwater and surface water. Three constituents that may be influenced by anthropogenic activity (chloride, boron, and nitrate plus nitrite) deviate from this pattern and show a wide distribution of concentrations in the unconfined aquifer, indicating possible anthropogenic influence.

Time-series plots of historical water-quality data indicated that nitrate does not seem to be increasing or decreasing in groundwater over time; however, time-series plots of chloride concentrations indicate that chloride may be increasing in some wells. The small amount of temporal variability in nitrate concentrations indicates a lack of major temporal changes to groundwater inputs.

\section{Introduction}

Some residents and resource managers in Blaine County, south-central Idaho, are increasingly concerned about how population growth may affect groundwater and surfacewater supplies, particularly the sustainability of groundwater resources and the effects of wastewater disposal on the quality of groundwater and surface-water sources. The population of Blaine County nearly quadrupled-growing from about 5,700 to 22,000 people-between 1970 and 2010 (Forstall, 1995; U.S. Census Bureau, 2011). In addition to permanent residents, the area also attracts many visitors for skiing, fishing, and other recreational activities. Most of the population growth and tourism has occurred in the northernmost part of the county in the Wood River Valley. The entire population of the valley depends on groundwater for domestic and public supply, either from privately-owned or municipal-supply wells; surface water is used for recreation and irrigation. In recent years, housing development has moved into tributary canyons of the Wood River Valley, and residents in some of these areas have reported declining groundwater levels. It is uncertain whether these declines were caused by the pumping that accompanied increased development or by several years of drought conditions.

Previous studies have addressed specific water-related issues or aspects of those issues in selected areas of the Wood River Valley. However, an updated, comprehensive evaluation of the water resources of the valley was needed to address concerns about the effects of current development and the potential effects of continued growth and development. In 2005, the U.S. Geological Survey (USGS), in cooperation with several local government agencies and organizations (Blaine County, the City of Hailey, the City of Ketchum, The Nature Conservancy, the City of Sun Valley, Sun Valley Water and Sewer District, Blaine Soil Conservation District, and the City 
of Bellevue), compiled and reviewed the existing information and data about the hydrology of Wood River Valley, identified gaps in information, and proposed a work plan with priorities for data collection and interpretation to fill those gaps. The objectives of that work plan were to: (1) provide data and interpretations about the water resources of the Wood River Valley to enable county and local governments to make informed decisions about managing those resources, (2) identify additional data collection or analyses that would assist decision makers, (3) construct a hydrogeologic framework for the Wood River Valley aquifer system, and (4) evaluate the quality of groundwater and surface-water supplies.

The first phase of the work plan, the development of groundwater-level maps comparing partial-development (1952-86) and 2006 conditions, and an analysis of hydrologic trends in the groundwater and surface-water systems, was completed in 2007 (Skinner and others, 2007). The second phase, the development of a groundwater budget, was completed in 2009 (Bartolino, 2009). The third phase, construction of a hydrogeologic framework, was completed in 2012 (Bartolino and Adkins, 2012). This report documents the completion of the fourth and final phase of the 2005 work plan, an assessment of groundwater and surface-water quality.

\section{Purpose and Scope}

This report describes a water-quality assessment based on samples collected at 45 groundwater sites and 5 surfacewater sites in the Wood River Valley during July and August 2012. It includes a comparison of the 2012 data with historical water-quality data and a discussion of historical patterns in the concentrations of selected constituents. In response to public concern, nutrient concentrations in surface water and groundwater in the Wood River Valley were assessed during the summer of 2012. This report also discusses groundwater and surface-water quality in relation to other water-quality constituents. Findings reported here establish baseline waterquality conditions for July and August 2012 that can be used to assess potential changes in the future.

\section{Description of the Study Area}

The Wood River Valley of south-central Idaho extends from Galena Summit (at the head of the Big Wood River drainage north of the study area) southward to the Picabo and Timmerman Hills (fig. 1). The valley can be separated into upper and lower parts along an east-west line immediately south of Bellevue. The upper valley is narrow, broadening downstream to a maximum width of $2 \mathrm{mi}$; the lower valley opens into a triangular alluvial fan (the Bellevue Fan) about $9 \mathrm{mi}$ across at its southern end. The study area of this report is the part of the Wood River Valley that extends from Baker Creek southward to the Timmerman Hills with an areal extent of about $100 \mathrm{mi}^{2}$; the Wood River Valley surface-water system encompasses a similar area from Galena Summit to the outlets of the basin in the south. Additional information about the study area is available in Bartolino (2009).

The study area is within two Idaho climate divisions: the Central Mountains (Division 4) located north of the Bellevue Fan, and the Central Plains (Division 7) located in the Bellevue Fan (National Climatic Data Center, 2012). During the 120 months from October 2002 to October 2012, the Central Mountains were classified as being under drought conditions for 48 percent of the months, as defined by a Palmer Drought Severity Index (PDSI) of less than -0.5; the Central Mountains were under wet conditions 49 percent of the months, as defined by a PDSI of greater than -0.5 . In contrast, the Central Plains were under drought conditions for 66 percent of the months and under wet conditions for 25 percent of the months (National Climatic Data Center, 2012). Months that were not defined as drought months or wet months were defined as normal.

\section{Groundwater}

The Wood River Valley aquifer system has three components: a single, unconfined aquifer that underlies the entire valley; a deep, confined aquifer that is present only to the south of Baseline Road where the Bellevue Fan widens the valley (fig. 1); and a confining unit that separates the two aquifers in the area (Bartolino and Adkins, 2012). The aquifer system consists primarily of Quaternary alluvial sediments of the Wood River Valley, although Quaternary basalts and interbedded sediment are the primary source of groundwater in the southeastern part of the Bellevue Fan. In some areas, the underlying bedrock may be hydraulically connected to the sediments and basalts. However, the sediments and basalts likely contain a small percentage of available water in the aquifer system. Generally, these bedrock aquifers probably are separate from the Wood River Valley aquifer system. In areas such as tributary canyons, wells are completed into bedrock, but little is known about the hydrology in certain areas.

The confined aquifer is separated from the overlying unconfined aquifer by fine-grained lacustrine deposits. This confining unit thickens toward the south and, generally, as land-surface altitude decreases in the same direction, the potentiometric surface of the confined aquifer rises above the land surface, resulting in some flowing wells under artesian pressure. South of Gannett, near the westernmost extent of Quaternary basalt, the confining unit fingers out and the aquifer becomes solely unconfined again (Bartolino and Adkins, 2012).

Groundwater movement in the Wood River Valley aquifer system generally follows the land surface altitude, moving down-valley and southward to the Bellevue Fan, where it either enters the deeper confined aquifer, or remains in the shallow unconfined aquifer. Recharge is primarily 


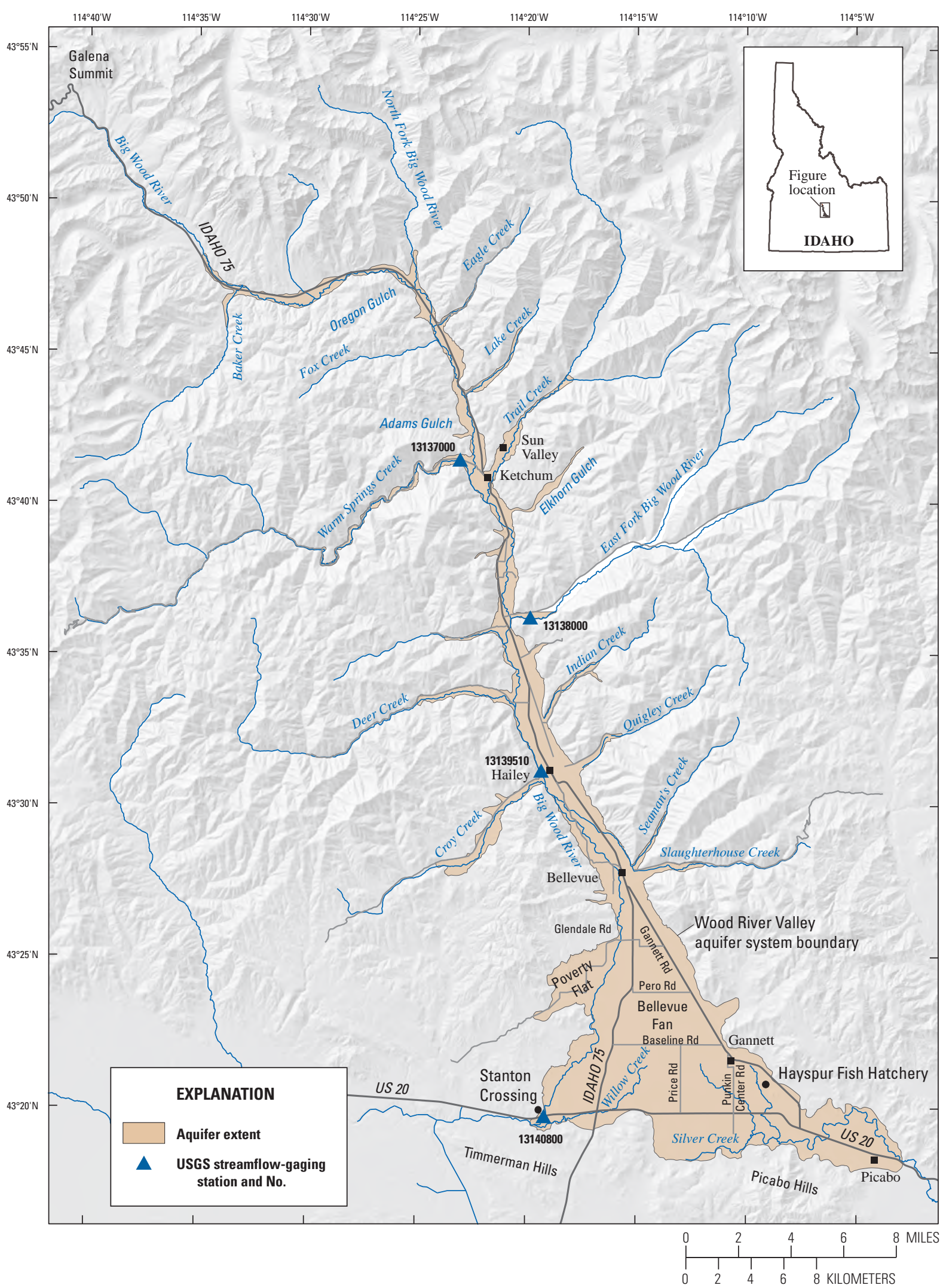

Figure 1. Locations of communities, selected U.S. Geological Survey streamgaging stations, and other features, Wood River Valley, south-central Idaho (modified from Bartolino and Adkins, 2012). 
from precipitation or seepage from streams, and discharge is primarily through springs and seeps to streams, pumpage, or subsurface outflow from the Wood River Valley aquifer system (Bartolino, 2009). The rerouting of surface water into a network of irrigation canals in the late 19th century, construction of groundwater wells, and increased demand have affected local groundwater flow paths, but the overall direction of groundwater movement remains down the topographic gradient and toward the eastern outlet of the valley at Picabo and the western outlet near Stanton Crossing.

Depth to groundwater in the upper (or northern) part of the valley commonly is less than $10 \mathrm{ft}$, increasing to about $90 \mathrm{ft}$ southward. Depth to water in wells completed in the unconfined aquifer in the lower (or southern) part of the valley ranges from less than $10 \mathrm{ft}$ to about $150 \mathrm{ft}$, whereas wells completed in the confined aquifer are under artesian pressure and flow where the potentiometric surface is above land surface (Skinner and others, 2007). A description of previous work on the hydrology of the Wood River Valley area related to groundwater-level maps and surface-water flows is included in Skinner and others (2007).

\section{Surface Water}

Most of the Wood River Valley is drained by the Big Wood River and its tributaries, except for the southeastern part of the Bellevue Fan, which is drained by southeastern flowing Silver Creek (fig. 1), a tributary to the Little Wood River (not shown in fig. 1). The Big Wood and Little Wood Rivers meet about $35 \mathrm{mi}$ southwest of the study area, where they join as the Malad River and flow southward to the Snake River (not shown in fig. 1). The Big Wood River originates near Galena Summit, about 20 mi northwest of Ketchum, gaining flow from a number of perennial and ephemeral tributaries as it meanders across the narrow upper valley. At Bellevue, the channel follows the western side of the Bellevue Fan (although water flow through most of this reach is ephemeral), finally exiting the valley at the Big Wood River at Stanton Crossing near Bellevue streamgage (13140800; fig. 1), an area fed by springs and seeps through part of the year. Spring-fed Silver Creek and its tributaries originate on the Bellevue Fan and flow eastward out of the valley at Picabo (fig. 1). Most of the streams in the tributary canyons to the Big Wood River are ephemeral and flow only in response to precipitation or snowmelt; however, North Fork Big Wood River, Warm Springs Creek, Trail Creek, East Fork Big Wood River, Deer Creek, and Croy Creek typically flow into the Big Wood River year-round. Streams in some of the smaller tributary canyons are perennial in their upper reaches, and some of this water likely infiltrates directly into the aquifer system, or reaches the Big Wood River by subsurface flow through streambed gravels. Most of the Wood River Valley was under irrigation by 1900 (Jones, 1952), and a well-developed network of irrigation canals and drains exists throughout the study area. The diversions and return flows between the irrigation system and the Big Wood River, as well as the exchange of water between the canals, drains, and streams and the underlying unconfined aquifer, contribute to changes in streamflow in the river as it flows downstream.

\section{Previous Investigations}

Numerous water-quality data collection efforts have been carried out in the Wood River Valley. Some studies did not include an interpretation of data, but provided baseline waterquality data for the study area. This section discusses the most relevant works and excludes aquatic biology studies.

Smith (1959) made the first detailed study of the Wood River Valley aquifer system in the Hailey and Bellevue Fan areas. This study provided laboratory analyses for 34 groundwater samples and 5 surface-water samples; all samples except one were collected in 1954. Smith's data were presented by Castelin and Chapman (1972), along with data from two additional samples collected in October 1970. Castelin and Chapman (1972, p. 43) addressed the Wood River Valley downstream of Hailey and concluded that groundwater and surface-water quality in the area was "suitable for nearly any use feasible in the basin.”

Castelin and Winner (1975) addressed the effects of urbanization on water resources in the Sun Valley-Ketchum area that they defined as the Big Wood River basin north of Hailey. One of the five objectives listed for the study was to "Determine the quality of ground and surface waters in the area,” (Castelin and Winner, 1975, p. 1). From August 1973 to May 1974, Castelin and Winner collected 28 samples at 12 surface-water sites on the Big Wood River and its tributaries between Baker Creek and Deer Creek. An additional 32 groundwater samples were collected from 14 wells between September 1973 and May 1974. Samples from all sites were analyzed for field water-quality parameters, major ions, nitrate, and boron. Five of the surface-water sites were sampled for zinc. Twelve surface-water sites from the Warm Springs Creek area to downstream of Bellevue were sampled 6 times between July 1972 and May 1974 for total coliform, fecal coliform, and fecal streptococci; additionally, diversity indices were calculated for stream biota at these 12 sites. Groundwater quality was determined to be adequate for all uses at the time; surface-water quality was determined to meet all standards set by the Idaho Department of Environmental and Community Services.

Consultants, including DesVoigne and others (1976), have conducted studies relating to wastewater-treatment plants in the Wood River Valley. In response to wastewater studies, the Idaho Department of Environmental Quality developed Total Maximum Daily Loads (TMDLs) for the Big Wood River basin and several tributaries in the Wood River Valley (Buhidar, 2002; Idaho Department of Environmental Quality, 2011). The agricultural component of the TMDL implementation plan was published by Pentzer (2006).

Minshall (1977) gathered water-quality data for six surface-water sites from 3 mi north of Ketchum to Stanton 
Crossing. These data were from samples collected by the State of Idaho, Parametrix Inc., and the Bureau of Reclamation. Minshall's report led to in-stream and laboratory experiments by Manuel and others (1978) that examined the effect of nutrients on aquatic plant growth in the Big Wood River between Ketchum and Hailey.

Luttrell and Brockway $(1982,1984)$ studied the effects of septic systems on water quality in the Wood River Valley from the North Fork Big Wood River to 3 mi south of Bellevue. They created a groundwater-monitoring network of 50 wells in the East Fork Big Wood River, Warm Springs Creek, and Bellevue areas. Samples were collected from these wells in the summer of 1983, and a subset of 26 wells was monitored every 6-8 weeks through March 1984. Samples were analyzed for nitrate, chloride, and orthophosphate; water quality was determined to vary seasonally. In a follow-up to this work, Schultz (1993) collected samples from 18 of the 26 original wells and determined that nitrate concentrations decreased from 1983 to 1992, whereas chloride concentrations slightly increased.

Frenzel (1989) collected groundwater and surface-water data to evaluate the effects of urbanization on water quality. Water-quality samples were collected in November 1986 and in March and August 1987 at seven surface-water and six groundwater sites from the Big Wood River near Ketchum streamgage (13135500, not shown in fig. 1) to Glendale Road. In addition to field water-quality parameters, samples were analyzed for nutrients, chloride, fluoride, sulfate, cadmium, lead, and zinc. Frenzel (1989, p. 32) concluded that, “... nutrient levels in the upper Big Wood River basin have not changed substantially during the past 30 years and that water quality is adequate for drinking and agricultural use."

In 2001, the Blaine County Commissioners "initiated the exploration of a tentative plan to monitor and protect drinking water in the unincorporated" areas of the county (Brown, 2002a, p.3). Brown (2002a) assessed previous work and ongoing monitoring by other agencies. This assessment was followed by the creation of a groundwater quality network of 16 wells that were sampled in 2002 to monitor bacteria, chloride, and nitrate (Brown, 2002b). The same 16 wells were sampled in 2003; the 16 wells and an additional 4 wells were sampled in 2004 (Brown, 2003, 2004). Brown evaluated trends in bacteria, chloride, and nitrate in the 2003 and 2004 reports. During the 3-year sampling period, none of the samples contained nitrate or chloride concentrations greater than the U.S. Environmental Protection Agency (EPA) maximum contaminant levels (MCLs).

Connolly and others (2003) developed a nitrogen mass-balance model of the Wood River basin that was used to calculate nitrogen loads. Projected future land use was modeled, and a watershed-based nitrogen trading system was developed.

Several studies have been published regarding the chemistry of geothermal waters in tributary canyons of the Wood River Valley. Anderson and Bideganeta (1985) examined six hot spring areas; their investigation included geochemical analyses of spring discharge. Another report included a section with isotopic analysis of spring and surface water in the Big Wood River drainage area (Mitchell, 1986). CH2M-Hill (1986) evaluated the Guyer Hot Springs system in the Warm Springs Creek drainage area for geothermal development, and included flow data for several springs. Renk (1986) sampled Warm Springs and Deer Creeks and the Big Wood River to determine the effects of geothermal spring discharge on stream-water quality and to determine the streams' capacity for additional geothermal discharge by estimating fluoride concentrations. Renk's study was followed by that of Burkett and Litke (1989) who described groundwater and surface-water conditions in the Warm Springs Creek area to determine sources of fluoride and potential water-quality effects of additional geothermal development. Street (1990) did a geochemical survey of six thermal and four non-thermal springs in the Wood River Valley.

Since the discovery of precious metals in the area in 1864 (Spence, 1999), numerous geochemical studies addressing the geology and mineralization of the Wood River Valley and the surrounding area have been published. The earliest reports include those of Eldridge (1896), Lindgren (1900), and Umpleby and others (1930). In addition to mineralogical description, the latter two reports included chemical analyses of ores and associated host rocks. Malcolm and Smith (1991) described analytical results for nearly 1,500 sediment samples collected in the Hailey, Idaho, 1:250,000 scale quadrangle. Minor elements and trace metals were included in the analyses. McIntyre (1985), Winkler and others (1989), and Worl and others (1995) contain a number of separate papers about geochemistry and mineralization in the area.

Historical mining activity has left many abandoned mines and prospect pits in the Wood River Valley and its tributary canyons. The EPA remediated two of these sites: tailings piles at the Triumph Mine on the East Fork Big Wood River and tailings piles at the Minnie Moore Mine west of Bellevue. Lead, arsenic, and other metals were the constituents of concern at Triumph; remediation work was completed in 2004 (U.S. Environmental Protection Agency, 2007). Lead and other metals were the constituents of concern at the Minnie Moore Mine; remediation work was completed in 2005 (U.S. Environmental Protection Agency, 2005).

Silver Creek and its biota have been the subject of many studies. Hauck (1947, p. 1) observed, "For over thirty years Silver Creek has been considered... one of the finest trout streams in the West.” In 1991, The Nature Conservancy (TNC) initiated monthly monitoring of discharge, $\mathrm{pH}$, water temperature, dissolved oxygen, turbidity, specific conductance, total dissolved solids, nutrients, sediment depth, and aquatic vegetation (Wolter and others, 1994). Davidson and Brown (2002) described TNC monitoring and results along three transects between June 2001 and September 2002. Data collection by TNC has continued and expanded (Ecosystem Sciences Foundation, 2012). 


\section{Study Methods and Quality Assurance}

\section{Site Selection}

Groundwater sampling sites were selected for an equal spatial distribution throughout the valley, with a preference given to wells that had been sampled previously; both private and public-supply wells were sampled. Wells were located and groundwater levels measured, in accordance with USGS Office of Ground Water Technical Procedures (Cunningham and Schalk, 2011). Surface-water sites were selected to represent different surface-water bodies in the study area.

The physical characteristics of the 45 wells sampled throughout the Wood River Valley vary spatially and with depth (fig. 2). Well depths vary throughout the study area based on their location, the aquifer that they are completed in, and their use (public-supply wells generally are deeper than domestic wells). The wells were selected and classified as completed in the confined aquifer ( 5 wells), bedrock aquifers in tributary canyons ( 7 wells), or unconfined aquifer (33 wells). Aquifer type was assigned based on drillers' reports and a well's location relative to the confining unit boundary defined by Skinner and others (2007). Alternate names were assigned (table 1 and fig. 2) based on the aquifer classification ( $\mathrm{C}$, confined aquifer; $\mathrm{T}$, bedrock aquifer in tributary canyons; $\mathrm{U}$, unconfined aquifer) and relative position in the valley increasing northward (for instance, U33 is the northern most unconfined well).The five surface-water sampling sites also were assigned an alternate name (SW, surface water). Sample sites are referred to by their alternate names in this report.

\section{Well Location and Identification}

Wells sampled for this study are identified by the 8-digit or 15-digit USGS site identification number as used in the USGS National Water Information System (NWIS), a Public Land Survey System (PLSS)-based well location commonly used by the Idaho Department of Water Resources (IDWR) and USGS (referred to as the "site name"), and an alternate name used in this report (table 1).

The PLSS-based well location system has been used in many historical reports as well as on IDWR drillers' reports. For example, 54N 04W 31DDD1 (fig. 3) designates a well in Township 54 North and Range 4 West; this $36 \mathrm{mi}^{2}$ area is the township. The numbers following the township indicate the section (31) within the township; the letters following the section indicate the quarter section (160-acre tract), quarter-quarter section (40-acre tract), and quarter-quarterquarter section (10-acre tract). The USGS designates quarter sections by the letters A, B, C, and D in counterclockwise order from the northeast quarter of each section. Within the quarter sections, 40 -acre and 10 -acre tracts are lettered in the same manner. For example, well 54N 04W 31DDD1 is in the southeast (SE) quarter of the SE quarter of the SE quarter of section 31. If multiple wells are present in the same tract, a number following the letters (1) designates the sequential number of the well. IDWR and well drillers' logs commonly use quarter sections instead of letters to designate the location of a well.

\section{Sample Collection}

Sample collection was done during a 2-month period from July to August 2012 to reduce seasonal variability. Water levels in wells were measured and wells were purged of at least three casing volumes before water samples were collected. Surface-water samples were collected using the depth-integrated equal-width-increment method (U.S. Geological Survey, variously dated, chap. 6.0.2A). At the time of sample collection, discharge was measured at surfacewater sites, and field parameters (temperature, $\mathrm{pH}$, specific conductance, dissolved oxygen, and alkalinity) were collected at all sites in accordance with USGS procedures (Turnipseed and Sauer, 2010; U.S. Geological Survey, variously dated).

\section{Quality Assurance/Quality Control}

This study followed the quality-assurance plan for the collection of water-quality samples of the USGS Idaho Water Science Center (Mark Hardy, U.S. Geological Survey, written commun., 2008). Field parameter meters were calibrated each day prior to sample collection. The quality of analytical results reported for water samples was evaluated using quality-control samples that were submitted from the field and analyzed concurrently in the laboratory with routine samples. The quality-control samples included eight replicate samples and one equipment blank. These quality-control samples provided quantitative information on the precision and bias of the overall field and laboratory processes. 


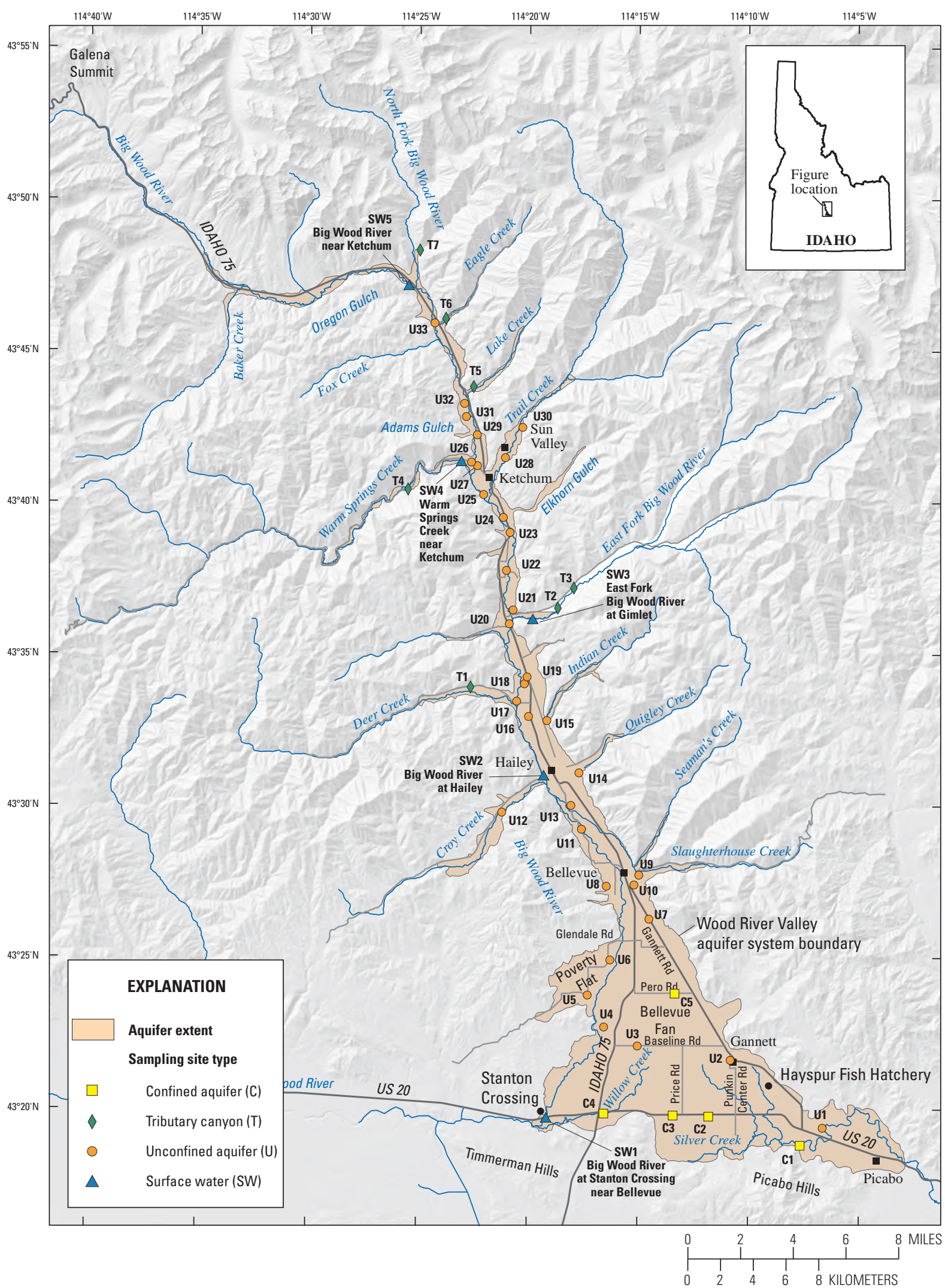

Figure 2. Groundwater and surface-water quality sites sampled in the Wood River Valley, Idaho, July and August 2012. 
Table 1. Site information, alternate names, and location information for groundwater and surface-water sampling sites in the Wood River Valley, south-central Idaho, July and August 2012.

[Site locations are shown in figure 2. Sites were classified by the aquifer or water body in which they were completed. Alternate name: Based on classification of site. L atitude and longitude: Based on North American Datum of 1927 (NAD 27) projection. Well depth: Obtained from well logs associated with U.S. Geological Survey (USGS) well numbers. M easured depth to water: Based on measurements taken at the time of sample collection. Water-level measurements

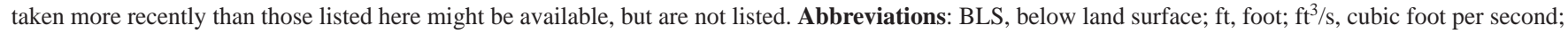
NGVD 29, National Geodetic Vertical Datum of 1929; n/a, not applicable; -, no data available]

\begin{tabular}{|c|c|c|c|c|c|c|c|c|c|}
\hline $\begin{array}{c}\text { USGS site } \\
\text { identification No. }\end{array}$ & $\begin{array}{c}\text { Site name or } \\
\text { identification No. }\end{array}$ & $\begin{array}{l}\text { Alternate } \\
\text { name }\end{array}$ & Latitude & Longitude & $\begin{array}{l}\text { Altitude } \\
\text { (ft above } \\
\text { NGVD 29) }\end{array}$ & Date & $\begin{array}{l}\text { Instant- } \\
\text { aneous } \\
\text { discharge } \\
\left(\mathrm{ft}^{3} / \mathrm{s}\right)\end{array}$ & $\begin{array}{c}\text { Well } \\
\text { depth } \\
\text { (ft BLS) }\end{array}$ & $\begin{array}{l}\text { Measured } \\
\text { depth to } \\
\text { water } \\
\text { (ft) }\end{array}$ \\
\hline \multicolumn{10}{|c|}{ Surface-water sampling sites } \\
\hline 13135500 & $\begin{array}{l}\text { Big Wood River near } \\
\text { Ketchum, Idaho }\end{array}$ & SW5 & $43^{\circ} 47^{\prime} 11^{\prime \prime}$ & $114^{\circ} 25^{\prime} 27^{\prime \prime}$ & 6,240 & 08-08-2012 & 97 & $\mathrm{n} / \mathrm{a}$ & $\mathrm{n} / \mathrm{a}$ \\
\hline 13138000 & $\begin{array}{l}\text { East Fork Big Wood River } \\
\text { at Gimlet, Idaho }\end{array}$ & SW3 & $43^{\circ} 36^{\prime} 11^{\prime \prime}$ & $114^{\circ} 19^{\prime} 49^{\prime \prime}$ & - & 08-07-2012 & 21 & $\mathrm{n} / \mathrm{a}$ & $\mathrm{n} / \mathrm{a}$ \\
\hline 13139510 & $\begin{array}{l}\text { Big Wood River at Hailey, } \\
\text { Total Flow }\end{array}$ & SW2 & $43^{\circ} 31^{\prime} 02^{\prime \prime}$ & $114^{\circ} 19^{\prime} 18^{\prime \prime}$ & 5,295 & 08-08-2012 & 232 & $\mathrm{n} / \mathrm{a}$ & $\mathrm{n} / \mathrm{a}$ \\
\hline 13140800 & $\begin{array}{l}\text { Big Wood River at } \\
\text { Stanton Crossing near } \\
\text { Bellevue, Idaho }\end{array}$ & SW1 & $43^{\circ} 19^{\prime} 45^{\prime \prime}$ & $114^{\circ} 19^{\prime} 09^{\prime \prime}$ & 4,830 & 08-08-2012 & 33 & $\mathrm{n} / \mathrm{a}$ & $\mathrm{n} / \mathrm{a}$ \\
\hline
\end{tabular}

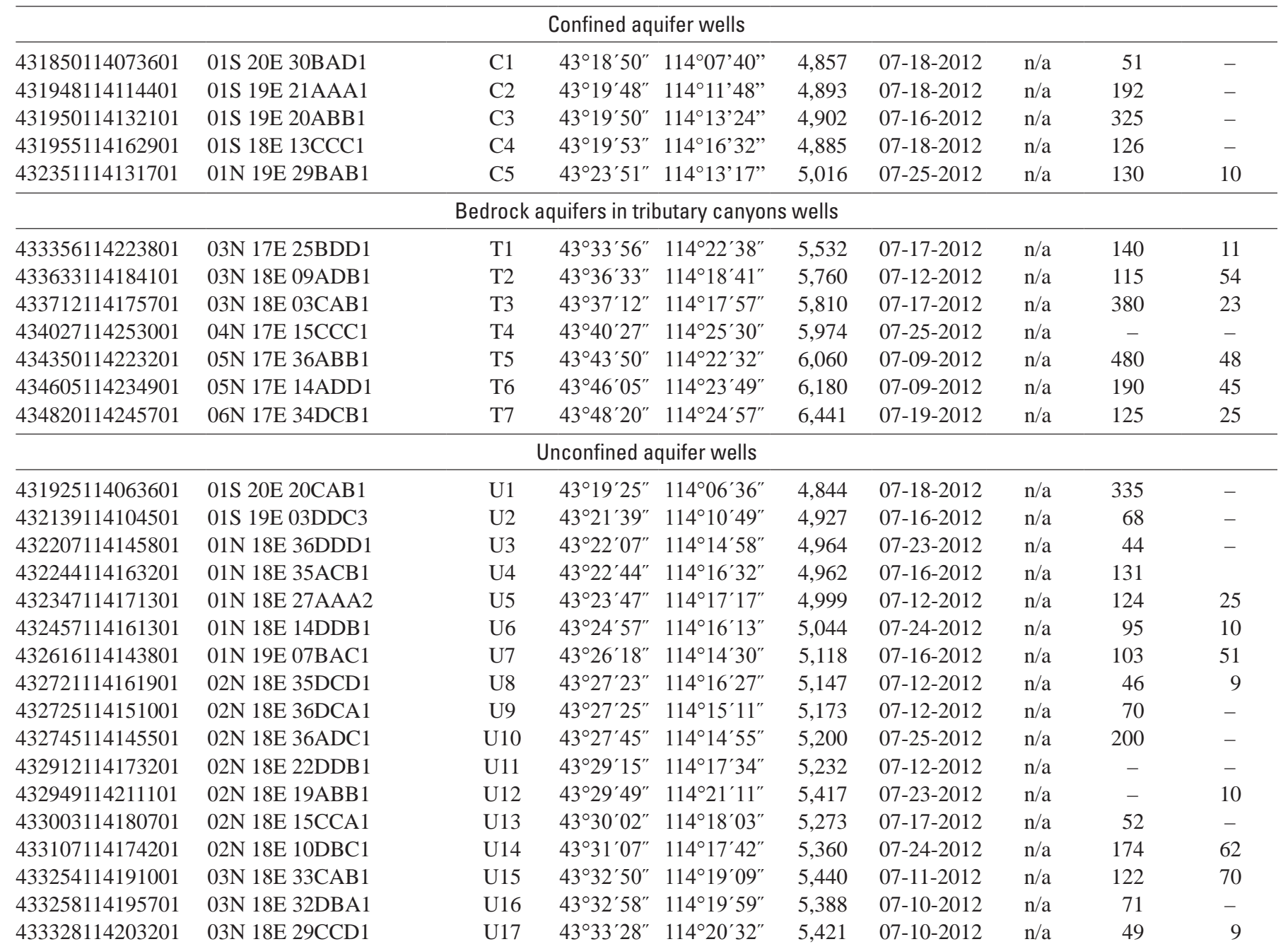


Table 1. Site information, alternate names, and location information for groundwater and surface-water sampling sites in the Wood River Valley, south-central Idaho, July and August 2012.—Continued

[Site locations are shown in figure 2. Sites were classified by the aquifer or water body in which they were completed. Alternate name: Based on classification of site. L atitude and longitude: Based on North American Datum of 1927 (NAD 27) projection. Well depth: Obtained from well logs associated with U.S. Geological Survey (USGS) well numbers. M easured depth to water: Based on measurements taken at the time of sample collection. Water-level measurements taken more recently than those listed here might be available, but are not listed. A bbreviations: BLS, below land surface; ft, foot; $\mathrm{ft}^{3} / \mathrm{s}$, cubic foot per second; NGVD 29, National Geodetic Vertical Datum of 1929; n/a, not applicable; -, no data available]

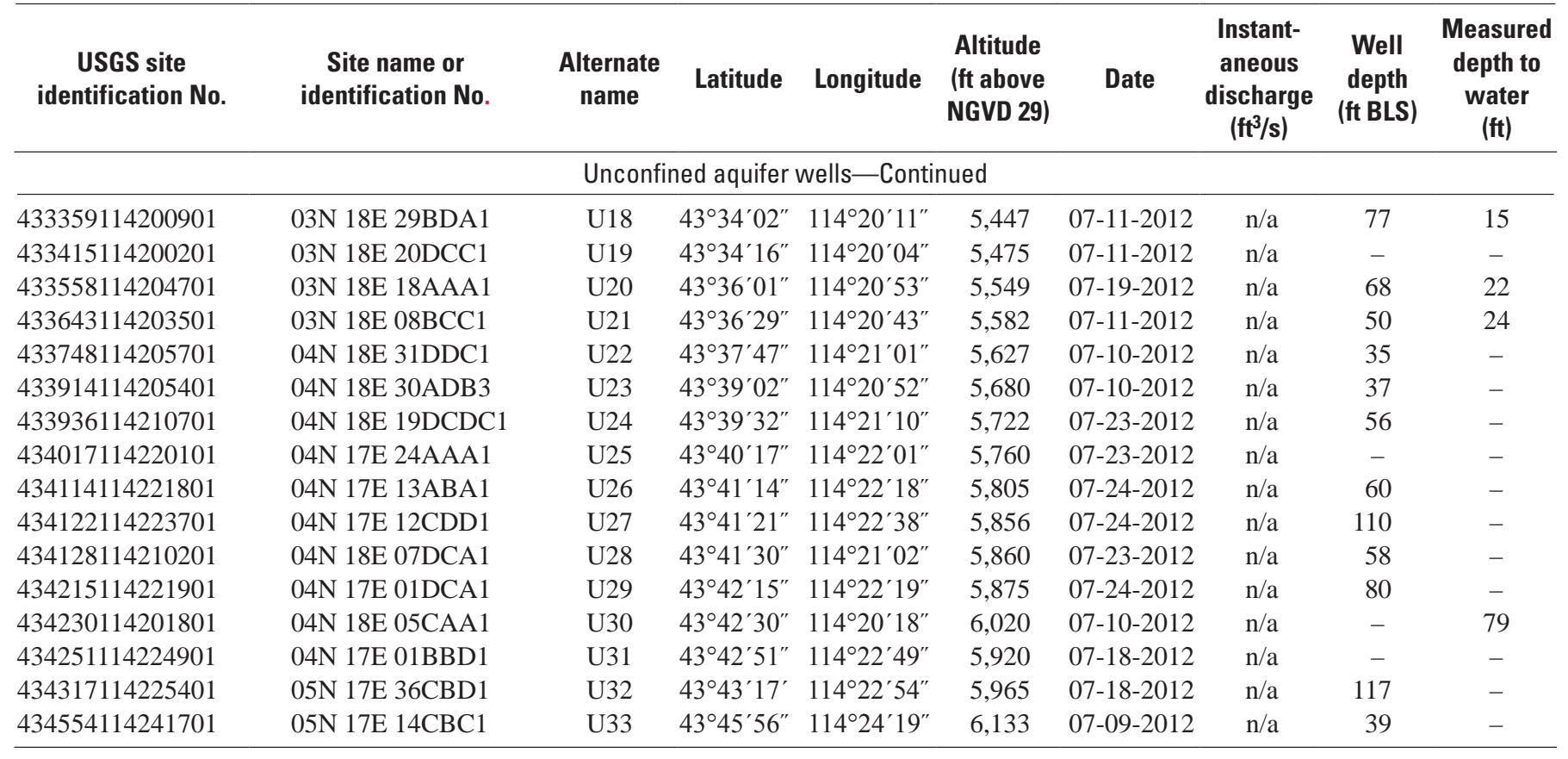

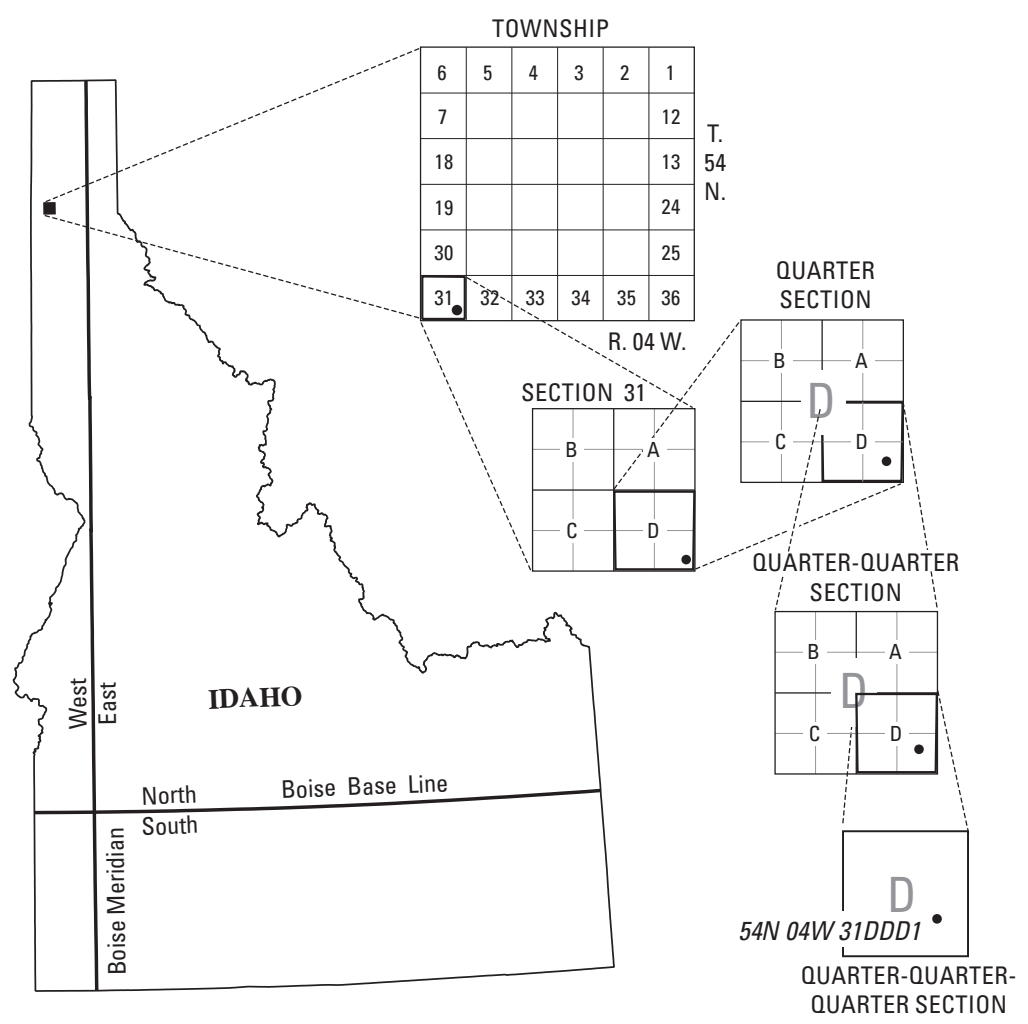

Figure 3. Well-numbering system used in Idaho by the U.S. Geological Survey to designate a site name. 


\section{Analytical Methods}

Samples were analyzed at laboratories for major cations, anions, selected trace elements, nutrients, and bacteria. The Idaho Department of Health and Welfare Laboratory in Boise, Idaho, analyzed E. coli and total coliform bacteria samples within 24 hours of collection using the Quanti-Tray technique (U.S. Geological Survey, variously dated, chapter 7.1.3E). Samples also were analyzed for the total coliform bacteria because the laboratory methodology produced counts for both types of bacteria; however, some samples produced erroneous total coliform data, and these values were not reported.

Results were listed as a count of the most probable number per $100 \mathrm{~mL}$; this value indicates the relative bacteria colony concentration in each sample.

All other samples were analyzed at the USGS National Water-Quality Laboratory in Lakewood, Colorado, with the standard analytical techniques described in Fishman and Friedman (1989). All data are stored in the USGS NWIS database.

The EPA standards for public drinking water (U.S. Environmental Protection Agency, 2012) were used as a guide to assess water quality in the Wood River Valley; the water-quality constituents analyzed for this study that have drinking-water standards are listed in table 2. The Idaho Department of Environmental Quality uses EPA standards to

Table 2. U.S. Environmental Protection Agency water-quality standards for drinking water for selected constituents analyzed in samples collected from groundwater and surface water in the Wood River Valley, south-central Idaho, July and August 2012.

[Some analytes measured for this study do not have drinking-water standards. M C L: Maximum contaminant level, an enforceable drinking-water standard that is health based. SM CL: Secondary maximum contaminant level, a non-enforceable drinking-water guideline based on aesthetic or cosmetic factors that do not affect the health of individuals consuming the water. Abbreviations: E. coli, Escherichia coli; $\mu \mathrm{g} / \mathrm{L}$, microgram per liter; mg/L, milligram per liter; -, guideline does not exist]

\begin{tabular}{lcc}
\hline \multicolumn{1}{c}{ Analyte name } & MCL & SMCL \\
\hline Total dissolved solids (mg/L) & - & 500 \\
pH (unit) & - & $6.5-8.5$ \\
Nitrate (as nitrogen) $(\mathrm{mg} / \mathrm{L})$ & 10 & - \\
Nitrite $($ as nitrogen) $(\mathrm{mg} / \mathrm{L})$ & 1 & - \\
Chloride $(\mathrm{mg} / \mathrm{L})$ & - & 250 \\
Sulfate $(\mathrm{mg} / \mathrm{L})$ & - & 250 \\
Fluoride $(\mathrm{mg} / \mathrm{L})$ & 4.0 & 2.0 \\
Iron $(\mu \mathrm{L} / \mathrm{L})$ & - & 300 \\
Manganese $(\mu \mathrm{g} / \mathrm{L})$ & - & 50 \\
Total coliforms count (including E.coli) & 0 & - \\
\hline
\end{tabular}

assess drinking-water quality in the state; therefore, the MCLs and secondary maximum contaminant levels (SMCLs) for Idaho are the same as those listed in table 2. These standards are presented as benchmark standards for concentrations in the samples. It is important to note that not all of the water analyzed in this study is used for drinking; some irrigation wells and surface-water sites do not provide drinking water and are not required to meet these standards.

\section{Data Compilation for Water-Quality Patterns}

Historical water-quality data (appendixes A and $\underline{B}$ ) provide a large spatial coverage of water quality in the Wood River Valley and can be combined with data from this study to examine potential changes in water quality over time. Although historical water-quality information exists for other constituents, appendixes A and $\underline{B}$ list information only for the constituents sampled for in this study.

All wells listed in appendix A are within the boundary of the Wood River Valley aquifer system and valley deposits. Some previous studies used the PLSS name, or an alternate name, for the well; data are listed under the available name. If a well from a previous study also has a USGS site identifier, it is listed with the data. Additional information about the well is available from U.S. Geological Survey (2013). Historical data collected by the USGS or IDWR were considered suitable for comparison because of consistent sampling methodology. Data from other studies were included if the methodology was judged to be consistent with USGS sampling and analytical methodology: Luttrell and Brockway (1984), Brown (2002a, 2003, 2004), and Sun Valley Water and Sewer District (Sun Valley Water and Sewer District, written commun., 2012). Three years of data (2009-12) from Sun Valley Water and Sewer District municipal-supply wells were available and included; some wells were excluded because their locations were not known. Data from Castelin and Chapman (1972) and Castelin and Winner (1975) were not used because their sampling methods were not known.

Water-quality data for surface-water sites in the study area (appendix B) include USGS data from NWIS and data from reports by Minshall (1977), Luttrell and Brockway (1984), and Wolter and others (1994). Stream discharge information was included, if available. Some data from Minshall (1977) were excluded because sampling techniques by outside agencies were not described. Sites with data for only physical parameters and discharge were not used. Samples known to be influenced by geothermal water were not used because those results are not representative of the Wood River aquifer system. 


\section{Quality of Groundwater and Surface Water}

\section{Water-Quality Conditions, July and August 2012}

Results of this study are representative of groundwaterand surface-water quality in the Wood River Valley during July and August 2012. The results can be used to establish baseline conditions for future water-quality studies in the Wood River Valley. Patterns in physical water-quality parameters and major ions can be extrapolated to patterns involving water quality throughout the valley. Nutrient concentrations and bacteria results are discussed relative to water-quality standards.

\section{Physical Water-Quality Parameters and Major Ions}

Physical water-quality parameters varied throughout the Wood River Valley (table 3). Water temperatures in groundwater samples ranged from 7.1 to $14.6^{\circ} \mathrm{C}$. Water temperatures in surface-water samples ranged from 10.0 to $15.9^{\circ} \mathrm{C}$. Total dissolved solids (TDS) concentrations ranged from 146 to $863 \mathrm{mg} / \mathrm{L}$ in groundwater, and from 92 to 178 $\mathrm{mg} / \mathrm{L}$ in surface water. TDS concentrations were from 146 to $863 \mathrm{mg} / \mathrm{L}$ in the unconfined aquifer, from 146 to $276 \mathrm{mg} / \mathrm{L}$ in the bedrock aquifers in tributary canyons, and from 172 to 216 $\mathrm{mg} / \mathrm{L}$ in the confined aquifer. Only one sample (well U30, with a concentration of $863 \mathrm{mg} / \mathrm{L}$ ) exceeded the EPA SMCL for TDS of $500 \mathrm{mg} / \mathrm{L}$. Well U30 is next to a small backyard pond; during sampling, the owner indicated that chlorine bleach (sodium hypochlorite, or $\mathrm{NaClO}$ ) and other chemicals had been frequently poured into this water body for disinfection. Because of the chemicals added, the shallow well U30 was considered to be anthropogenically influenced and was excluded from figures and further evaluation in this study.

Groundwater starts as a relatively dilute water recharged by precipitation and picks up solutes from interaction with aquifer materials and anthropogenic sources; these interactions are evident in the concentrations of solutes and TDS.

Concentrations of TDS varied by aquifer in the Wood River Valley (fig. 4), with the widest range of concentrations in the bedrock aquifers in tributary canyons and the unconfined aquifer. Some water samples collected from wells in bedrock aquifers in tributary canyons had TDS concentrations higher than the nearby unconfined aquifer, suggestive of groundwater interacting with the bedrock. The large range in TDS in the unconfined aquifer may be partly due to anthropogenic influences, such as irrigation, which has been ongoing since the early 1900s. The small range in TDS values in the confined aquifer suggests a relatively homogenous chemistry throughout the spatially distributed sites, perhaps because of isolation from anthropogenic influence, or perhaps because of the presence of old water unaffected by evapotranspiration. Age tracers, stable isotopes, and anthropogenic contaminants could be analyzed in future studies of the confined aquifer to determine the source and age of recharge to the confined aquifer. The variability of TDS and other major ions in each hydrologic system is shown in figure 4. Generally, the variations in naturally-occurring analytes mimic the patterns of TDS, with the greatest variability in concentrations in the unconfined aquifer. Boxplots in figure 4 confirm the pattern of relatively homogenous chemistry in the confined aquifer.

Table 3. Physical parameters of groundwater and surface-water samples, Wood River Valley, south-central Idaho, July and August 2012.

[Site locations are shown in figure 2. Values exceeding U.S. Environmental Protection Agency guidelines (from table 2) in bold. Alternate name: C, confined aquifer; SW, surface water; T, bedrock aquifer in tributary canyon; U, unconfined aqufer. A bbreviations: $\mathrm{CaCO}_{3}$, calcium carbonate; ${ }^{\circ} \mathrm{C}$, degrees Celsius; HH:MM, hour:minute; mg/L, milligram per liter; $\mu \mathrm{S} / \mathrm{cm}$, microsiemens per centimeter at 25 degrees Celsius; $\mathrm{M}$, presence verified but not quantified; -, no data available]

\begin{tabular}{|c|c|c|c|c|c|c|c|c|c|}
\hline $\begin{array}{l}\text { Site identification } \\
\text { name or No. }\end{array}$ & $\begin{array}{l}\text { Alternate } \\
\text { name }\end{array}$ & $\begin{array}{l}\text { Sample } \\
\text { date }\end{array}$ & $\begin{array}{c}\text { Sample } \\
\text { time }\end{array}$ & $\begin{array}{c}\text { Water } \\
\text { temperature, } \\
\text { field } \\
\left({ }^{\circ} \mathrm{C}\right)\end{array}$ & $\begin{array}{c}\text { Specific } \\
\text { conductance, } \\
\text { field } \\
(\mu \mathrm{S} / \mathrm{cm})\end{array}$ & $\begin{array}{c}\text { Dissolved } \\
\text { oxygen } \\
\text { (mg/L) }\end{array}$ & $\mathrm{pH}$ & $\begin{array}{c}\text { Total } \\
\text { dissolved } \\
\text { solids } \\
\text { (mg/L) }\end{array}$ & $\begin{array}{c}\text { Alkalinity } \\
\text { (mg/L as } \\
\mathrm{CaCO}_{3} \text { ) }\end{array}$ \\
\hline $\begin{array}{l}\text { Big Wood River near } \\
\text { Ketchum, Idaho }\end{array}$ & SW5 & 08-08-2012 & 1155 & 10.0 & - & 9.1 & 8.4 & 92.0 & 72.4 \\
\hline $\begin{array}{l}\text { Warm Springs Creek near } \\
\text { Ketchum, Idaho }\end{array}$ & SW4 & 08-07-2012 & 1130 & 15.9 & 223 & 8.8 & 8.3 & 144 & 97.9 \\
\hline $\begin{array}{l}\text { Big Wood River at Hailey, } \\
\text { Total Flow }\end{array}$ & SW2 & 08-08-2012 & 1435 & 14.3 & 263 & 8.6 & 8.6 & 155 & 120 \\
\hline Big Wood River at Stanton & SW1 & 08-08-2012 & 0850 & 15.3 & 292 & 7.1 & 7.9 & 178 & 133 \\
\hline
\end{tabular}


Table 3. Physical parameters of groundwater and surface-water samples, Wood River Valley, south-central Idaho, July and August 2012.-Continued

[Site locations are shown in figure 2. Values exceeding U.S. Environmental Protection Agency guidelines (from table 2) in bold. Alternate name: C, confined aquifer; SW, surface water; T, bedrock aquifer in tributary canyon; $\mathrm{U}$, unconfined aqufer. A bbreviations: $\mathrm{CaCO}_{3}$, calcium carbonate; ${ }^{\circ} \mathrm{C}$, degrees Celsius; HH:MM, hour:minute; $\mathrm{mg} / \mathrm{L}$, milligram per liter; $\mu \mathrm{S} / \mathrm{cm}$, microsiemens per centimeter at 25 degrees Celsius; $\mathrm{M}$, presence verified but not quantified; -, no data available]

\begin{tabular}{|c|c|c|c|c|c|c|c|c|c|}
\hline $\begin{array}{l}\text { Site identification } \\
\text { name or No. }\end{array}$ & $\begin{array}{c}\text { Alternate } \\
\text { name }\end{array}$ & $\begin{array}{l}\text { Sample } \\
\text { date }\end{array}$ & $\begin{array}{c}\text { Sample } \\
\text { time }\end{array}$ & $\begin{array}{l}\text { Water } \\
\text { temperature, } \\
\text { field } \\
\left({ }^{\circ} \mathrm{C}\right)\end{array}$ & $\begin{array}{c}\text { Specific } \\
\text { conductance, } \\
\text { field } \\
(\mu \mathrm{S} / \mathrm{cm})\end{array}$ & $\begin{array}{c}\text { Dissolved } \\
\text { oxygen } \\
\text { (mg/L) }\end{array}$ & $\mathrm{pH}$ & $\begin{array}{c}\text { Total } \\
\text { dissolved } \\
\text { solids } \\
\text { (mg/L) }\end{array}$ & $\begin{array}{c}\text { Alkalinity } \\
\text { (mg/L as } \\
\left.\mathrm{CaCO}_{3}\right)\end{array}$ \\
\hline 01S 20E 30BAD1 & C1 & 07-18-2012 & 1230 & 11.6 & 341 & 7.5 & 8.6 & 216 & 176 \\
\hline 01S 19E 21AAA1 & $\mathrm{C} 2$ & 07-18-2012 & 0820 & 8.9 & 272 & 7.7 & 7.8 & 172 & 129 \\
\hline 01S 19E 20ABB1 & C3 & 07-16-2012 & 0845 & 9.1 & 288 & 9.3 & 6.9 & 177 & 141 \\
\hline 01S 18E 13CCC1 & $\mathrm{C} 4$ & 07-18-2012 & 1000 & 9.8 & 296 & 9.9 & 9.8 & 180 & 135 \\
\hline 01N 19E 29BAB1 & C5 & 07-25-2012 & 1005 & 11.1 & 349 & 7.9 & 8.0 & 205 & 159 \\
\hline 03N 17E 25BDD1 & $\mathrm{T} 1$ & 07-17-2012 & 1530 & 9.0 & 333 & 8.1 & 9.0 & 220 & 172 \\
\hline 03N 18E 09ADB1 & $\mathrm{T} 2$ & 07-12-2012 & 0915 & 8.8 & 371 & 6.2 & 8.0 & 222 & 170 \\
\hline 03N 18E 03CAB1 & T3 & 07-17-2012 & 1235 & 10.8 & 464 & $<2$ & 7.9 & 276 & 205 \\
\hline 04N 17E 15CCC1 & $\mathrm{T} 4$ & 07-25-2012 & 1205 & 11.9 & 287 & 5.7 & 8.1 & 146 & 112 \\
\hline 05N 17E 36ABB1 & $\mathrm{T} 5$ & 07-09-2012 & 1035 & 13.6 & 259 & 0.40 & 9.7 & 206 & 142 \\
\hline 05N 17E 14ADD1 & T6 & 07-09-2012 & 1310 & 9.4 & 314 & 8.0 & 7.7 & 182 & 160 \\
\hline 06N 17E 34DCB1 & $\mathrm{T} 7$ & 07-19-2012 & 1500 & 13.9 & 303 & 8.4 & 7.5 & 185 & 168 \\
\hline 01S 20E 20CAB1 & $\mathrm{U} 1$ & 07-18-2012 & 1205 & 18.8 & 429 & 8.4 & 8.6 & 257 & 211 \\
\hline 01S 19E 03DDC3 & $\mathrm{U} 2$ & 07-16-2012 & 1415 & 11.2 & 460 & 8.2 & 7.8 & 268 & 204 \\
\hline 01N 18E 36DDD1 & U3 & 07-23-2012 & 1520 & 11.1 & 311 & 8.2 & 7.4 & 186 & 138 \\
\hline 01N 18E 35ACB1 & $\mathrm{U} 4$ & 07-16-2012 & 1235 & 11.8 & 348 & 9.9 & 8.0 & 208 & 155 \\
\hline 01N 18E 27AAA2 & U5 & 07-12-2012 & 1445 & 12.0 & 315 & 8.8 & 7.6 & 196 & 150 \\
\hline 01N 18E 14DDB1 & U6 & 07-24-2012 & 1245 & 8.5 & 232 & 8.9 & 6.3 & 146 & 112 \\
\hline 01N 19E 07BAC1 & U7 & 07-16-2012 & 1045 & 11.0 & 367 & 6.7 & 8.0 & 213 & 165 \\
\hline 02N 18E 35DCD1 & U8 & 07-12-2012 & 1215 & 9.5 & 387 & 4.7 & 7.8 & 157 & 29.0 \\
\hline 02N 18E 36DCA1 & U9 & 07-12-2012 & 1335 & 8.9 & 400 & 4.3 & 7.9 & 248 & 204 \\
\hline 02N 18E 36ADC1 & U10 & 07-25-2012 & 0850 & 14.0 & 340 & 9.4 & 8.0 & 181 & 139 \\
\hline 02N 18E 22DDB1 & U11 & 07-12-2012 & 1050 & 8.1 & 376 & 3.1 & 7.9 & 224 & 181 \\
\hline 02N 18E 19ABB1 & U12 & 07-23-2012 & 1320 & 10.5 & 301 & 7.7 & 7.6 & 189 & 120 \\
\hline 02N 18E 15CCA1 & U13 & 07-17-2012 & 1400 & 10.4 & 458 & 5.8 & 8.0 & 265 & 200 \\
\hline 02N 18E 10DBC1 & U14 & 07-24-2012 & 1345 & 14.6 & 487 & 8.3 & 8.3 & 283 & 212 \\
\hline 03N 18E 33CAB1 & U15 & 07-11-2012 & 1250 & 10.5 & 407 & 7.6 & 8.0 & 246 & 199 \\
\hline 03N 18E 32DBA1 & U16 & 07-10-2012 & 1530 & 13.9 & 363 & 5.1 & 7.8 & 219 & 176 \\
\hline 03N 18E 29CCD1 & U17 & 07-10-2012 & 1150 & 9.1 & 267 & 5.5 & 8.2 & 162 & 122 \\
\hline 03N 18E 29BDA1 & U18 & 07-11-2012 & 1050 & 9.7 & 344 & 4.8 & 8.1 & 201 & 156 \\
\hline 03N 18E 20DCC1 & U19 & 07-11-2012 & 1430 & 9.5 & 358 & - & 8.1 & 213 & 165 \\
\hline 03N 18E 18AAA1 & U20 & 07-19-2012 & 1000 & 8.7 & 304 & 7.0 & 8.1 & 176 & 142 \\
\hline 03N 18E 08BCC1 & U21 & 07-11-2012 & 0920 & 8.5 & 365 & 4.6 & 7.8 & 209 & 174 \\
\hline 04N 18E 31DDC1 & U22 & 07-10-2012 & 1015 & 7.6 & 290 & 3.8 & 8.0 & 171 & 137 \\
\hline 04N 18E 30ADB3 & U23 & 07-10-2012 & 0900 & 7.9 & 282 & 4.7 & 8.1 & 168 & 137 \\
\hline 04N 18E 19DCDC1 & U24 & 07-23-2012 & 1120 & 10.9 & 290 & 5.5 & 8.1 & 160 & 117 \\
\hline 04N 17E 24AAA1 & U25 & 07-23-2012 & 1055 & 8.5 & 284 & 4.6 & 8.0 & 166 & 128 \\
\hline 04N 17E 13ABA1 & U26 & 07-24-2012 & 1000 & 7.8 & 247 & 5.1 & 7.8 & 151 & 127 \\
\hline 04N 17E 12CDD1 & U27 & 07-24-2012 & 1020 & 11.9 & 361 & 8.0 & 7.9 & 233 & 166 \\
\hline 04N 18E 07DCA1 & U28 & 07-23-2012 & 1020 & 8.8 & 393 & 8.2 & - & 220 & 172 \\
\hline 04N 17E 01DCA1 & U29 & 07-24-2012 & 1050 & 7.1 & 260 & 6.1 & 8.0 & 156 & 129 \\
\hline 04N 18E 05CAA1 & U30 & 07-10-2012 & 1345 & 11.6 & 1,210 & 1.4 & 6.8 & 863 & 426 \\
\hline 04N 17E 01BBD1 & U31 & 07-18-2012 & 1420 & 8.9 & 259 & 5.8 & 8.9 & 154 & 127 \\
\hline 05N 17E 36CBD1 & U32 & 07-18-2012 & 1500 & 7.5 & 290 & 6.2 & 8.5 & 168 & 135 \\
\hline 05N 17E 14CBC1 & U33 & 07-09-2012 & 0900 & 9.2 & 266 & 5.3 & 8.0 & 158 & 130 \\
\hline
\end{tabular}



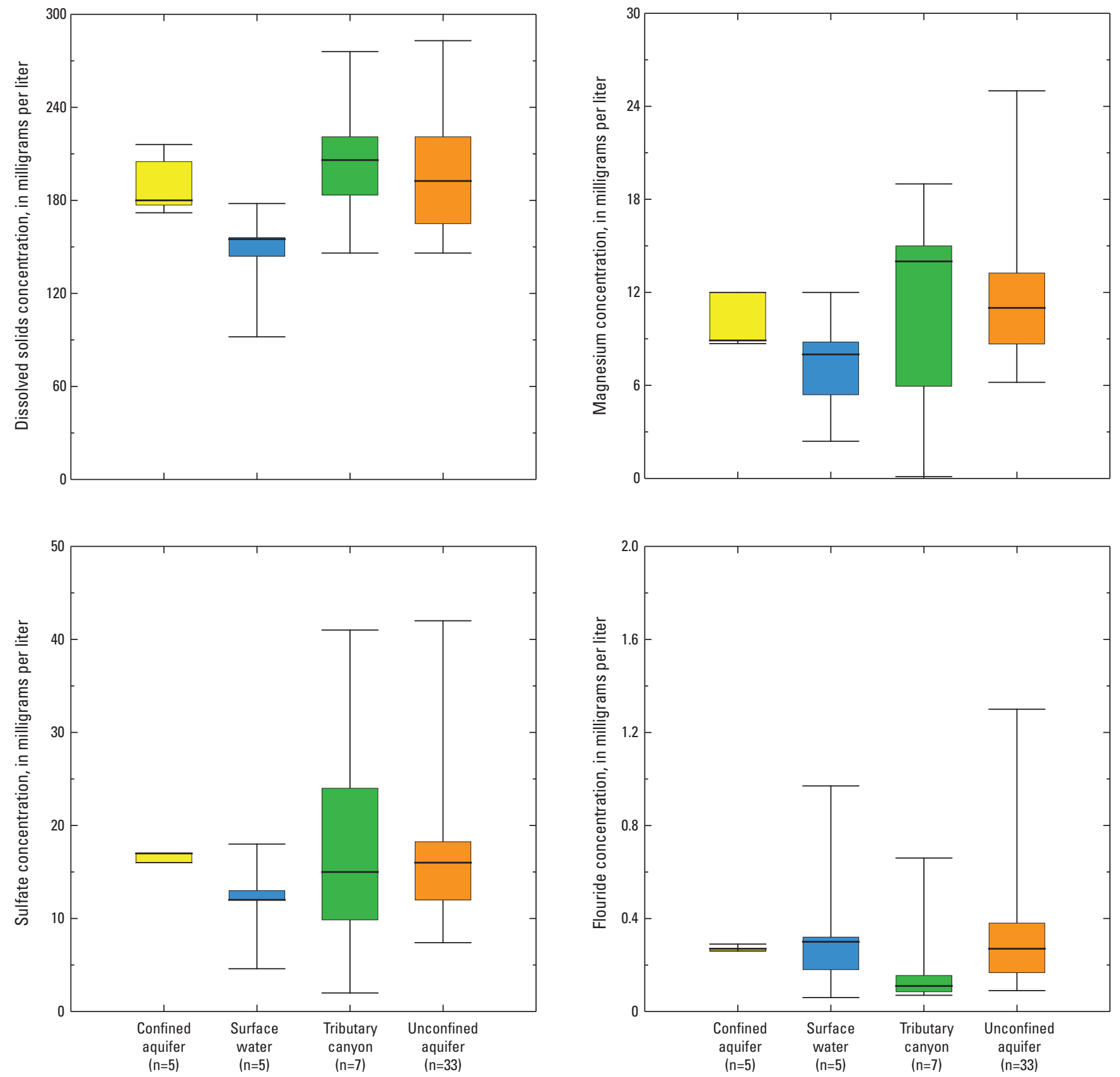

EXPLANATION

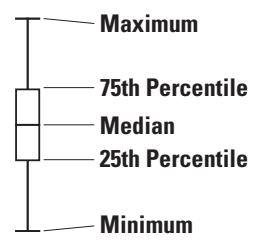

Figure 4. Total dissolved solids, magnesium, sulfate, and fluoride concentrations in groundwater and surface-water samples, Wood River Valley, south-central Idaho, July and August 2012. Well U30 is not included in this figure because of suspected contamination. 
Major ion concentrations (table 4) are used as the main descriptor of water composition and can help to identify geologic and anthropogenic effects on a water sample. Major anions analyzed in this study included chloride (Cl), sulfate $\left(\mathrm{SO}_{4}\right)$, fluoride $(\mathrm{F})$, and alkalinity (carbonate and bicarbonate, table 3). Major cations evaluated in this study were calcium $(\mathrm{Ca})$, magnesium $(\mathrm{Mg})$, sodium $(\mathrm{Na})$ and potassium $(\mathrm{K})$. Major ion concentrations, with the exception of chloride, tended to follow the pattern of distribution between aquifers seen in TDS.

Major ion concentrations determine water type and indicate a relatively consistent chemistry throughout the study area. Most samples collected (43) were a calcium-magnesiumbicarbonate type water when plotted on a trilinear diagram (Piper, 1944) (fig. 5). Six samples from the unconfined aquifer, bedrock aquifers in tributary canyons, and surface water plotted as calcium-bicarbonate type water and one sample (T5) from the Lake Creek drainage plotted as a sodium-bicarbonate type water. These water types are typical of relatively pristine groundwater that has not undergone significant geochemical interaction. The relatively consistent water type throughout the study area suggests that similar geochemical reactions, or lack of reactions, and similar anthropogenic influences are affecting the various locations of groundwater and surface water in the study area.

Samples also were analyzed for silica, iron, boron, and manganese. An abundance of silicate minerals exist in the Wood River Valley, including minerals from the Challis Volcanics, Idavada Volcanics, Idaho Batholith, Copper Basin Formation, and alluvium (Worl and Johnson, 1995). Silica (as $\mathrm{SiO}_{2}$ ) concentrations ranged from 6.1 to $50 \mathrm{mg} / \mathrm{L}$ in groundwater and from 7.9 to $21 \mathrm{mg} / \mathrm{L}$ in surface water; higher concentrations of silica in groundwater than in surface water indicate increased interaction with geologic sources, possibly due to longer residence times in the aquifer. Manganese concentrations in the Wood River Valley ranged from less than the detection limit $(0.16 \mu \mathrm{g} / \mathrm{L})$ to $16 \mu \mathrm{g} / \mathrm{L}$ in groundwater, and from 0.74 to $33 \mu \mathrm{g} / \mathrm{L}$ in surface water. All samples were less than the EPA SMCL for manganese $(50 \mu \mathrm{g} / \mathrm{L})$. Only one sample (T3, collected from the East Fork of the Big Wood River drainage, with a concentration of $1,200 \mu \mathrm{g} / \mathrm{L}$ ) exceeded the $300 \mu \mathrm{g} / \mathrm{L}$ EPA SMCL for iron; this well is a rarely used irrigation well, and flakes from the well casing may have contaminated the sample.

Generally, surface-water and groundwater samples met EPA guidelines for drinking-water quality. All concentrations of chloride, fluoride, and sulfate in groundwater and surface water were less than the EPA MCLs and SMCLs (U.S. Environmental Protection Agency, 2012). Chloride concentrations from this study are generally in the same range as chloride concentrations reported in previous studies (Luttrell and Brockway, 1984; Schultz, 1993; and Brown, 2002a, 2003, and 2004). However, chloride concentrations show a different pattern of distribution between aquifers than TDS and other major ions, with a larger range of chloride concentrations in the unconfined aquifer than in other aquifers (fig. 6). Chloride concentrations may increase in response to anthropogenic sources, such as road salts and chlorine tablets used for well decontamination, and the large range of concentrations in the unconfined aquifer may be indicative of anthropogenic influences.

\section{Nutrients}

Sources of nutrients (nitrogen and phosphorus containing compounds) in the study area suggested by Connolly and others (2003) include atmospheric deposition, application of fertilizer, nitrogen fixation, livestock waste, and domestic wastewater from septic systems and municipal wastewater treatment plants. Three wastewater-treatment facilities in the study area treat sewage and discharge to the Big Wood River (Bartolino, 2009). However, many homes in the study area rely on septic systems for wastewater disposal. If septic systems leak, untreated or partially treated wastewater may contaminate nearby groundwater; therefore, boron and bacteria were analyzed to help to determine if wastewater is contributing to nutrient concentrations in groundwater.

Nitrate and nitrite concentrations in all samples were less than the EPA MCLs and often were less than detection limits. Little variation in nitrite and ammonia concentrations was noted in groundwater and surface-water samples collected in the study area (table 5). Ammonia concentrations in water samples collected from wells rarely exceeded the detection limit of $0.010 \mathrm{mg} / \mathrm{L}$ as nitrogen. The highest concentration was $0.019 \mathrm{mg} / \mathrm{L}$ in $\mathrm{U} 1$; ammonia did not exceed the detection limit in any of the surface-water samples. Only one sample from the confined aquifer $(\mathrm{C} 1)$ and two other samples from the unconfined aquifer (U1, and U10) contained detectable concentrations of ammonia.

Boron is present in many soaps and cleansers and was analyzed to help identify sources of high-nutrient waters associated with domestic use. Boron has few possible geological sources in the study area (marine sediments, granite, and thermal springs), yet concentrations varied in study area samples from 3.8 to $37 \mu \mathrm{g} / \mathrm{L}$ (fig. 6). The widest distribution of concentrations was in the unconfined aquifer. A cross plot of boron and nitrate plus nitrite as nitrogen (fig. 7) does not display a clear relationship $\left(\mathrm{R}^{2}=0.058\right.$ in groundwater samples). Similarly, boron and phosphate did not show any distinct relation. Some samples had high concentrations of boron and high concentrations of nitrate plus nitrite, indicating that these samples may be sourced from domestic wastewater (perhaps from septic systems). However, not all nitrate plus nitrite was sourced from domestic wastewater because some samples showed high concentrations of nutrients and low concentrations of boron relative to area groundwater, suggesting an agricultural source of nutrients. Samples with high nitrate plus nitrite values (greater than $1.5 \mathrm{mg} / \mathrm{L}$ ) and low boron values (less than $15 \mu \mathrm{g} / \mathrm{L}$ ) were collected from wells drawing from the unconfined aquifer in both the Bellevue Fan, and in or near Quigley and Croy Creek tributary canyons. 
Table 4. Major ion and selected trace element concentrations in groundwater and surface-water samples, Wood River Valley, southcentral Idaho, July and August 2012.

[Site locations are shown in figure 2. Values exceeding U.S. Environmental Protection Agency guidelines in bold. Alternate name: C, confined aquifer; SW, surface water; T, bedrock aquifer in tributary canyons; $\mathrm{U}$, confined aquifer. A bbreviations: $\mathrm{mg} / \mathrm{L}$, milligram per liter; $\mu \mathrm{g} / \mathrm{L}$, microgram per liter; $\mathrm{SiO}_{2}$, silicon dioxide; <, less than; -, no data available]

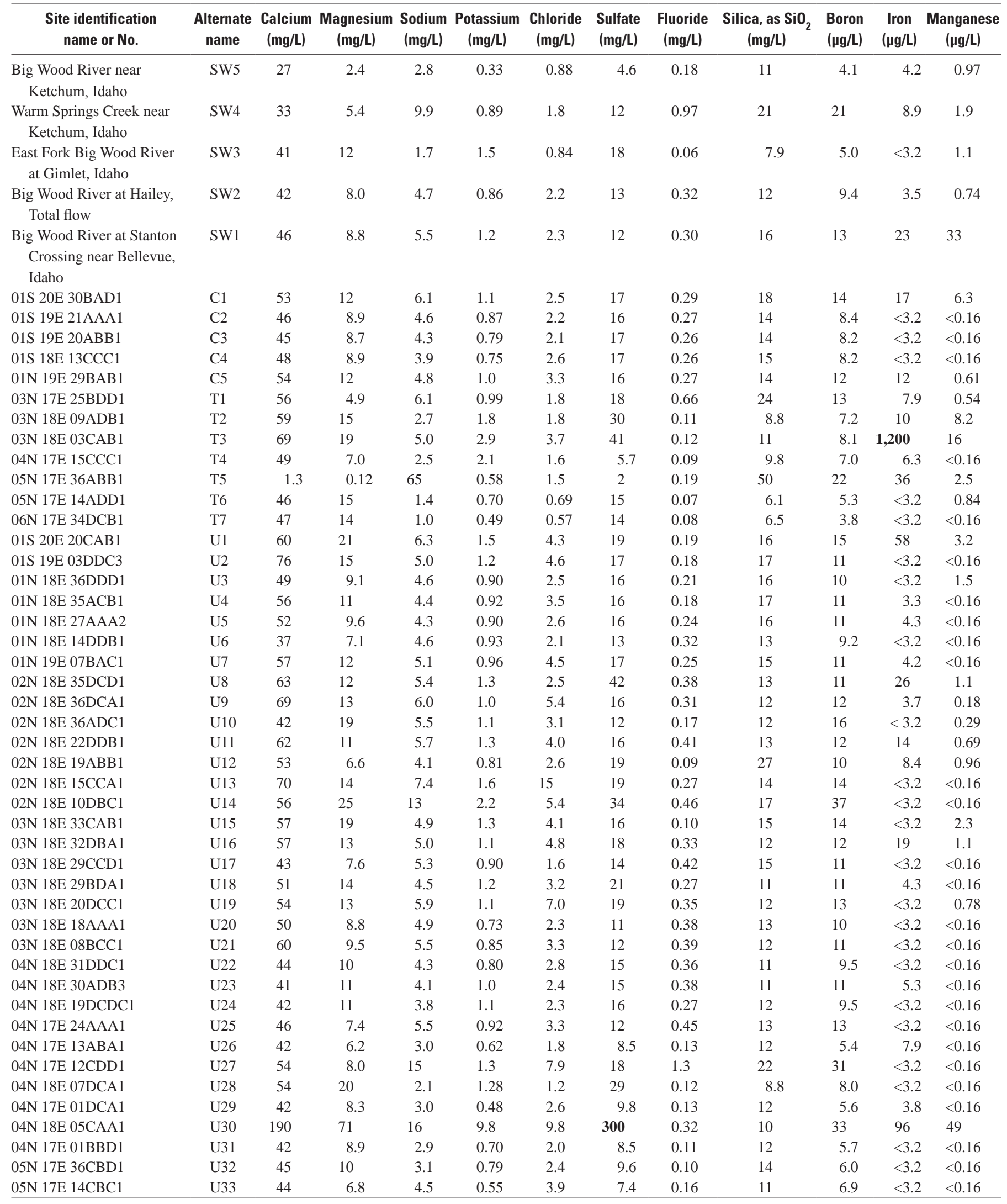




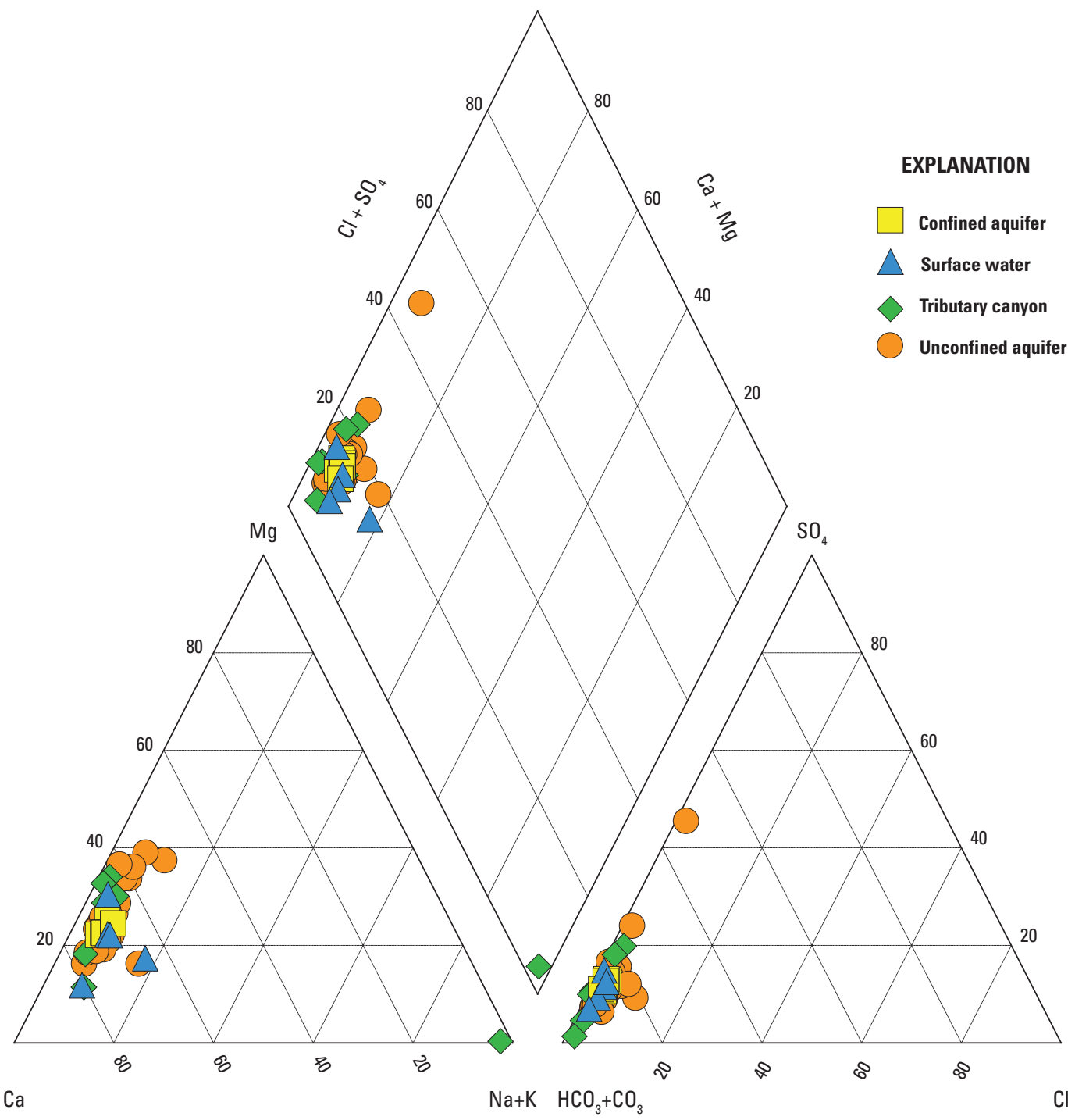

Figure 5. Relative composition of major ions in groundwater and surface-water samples, Wood River Valley, south-central Idaho, July and August 2012. 

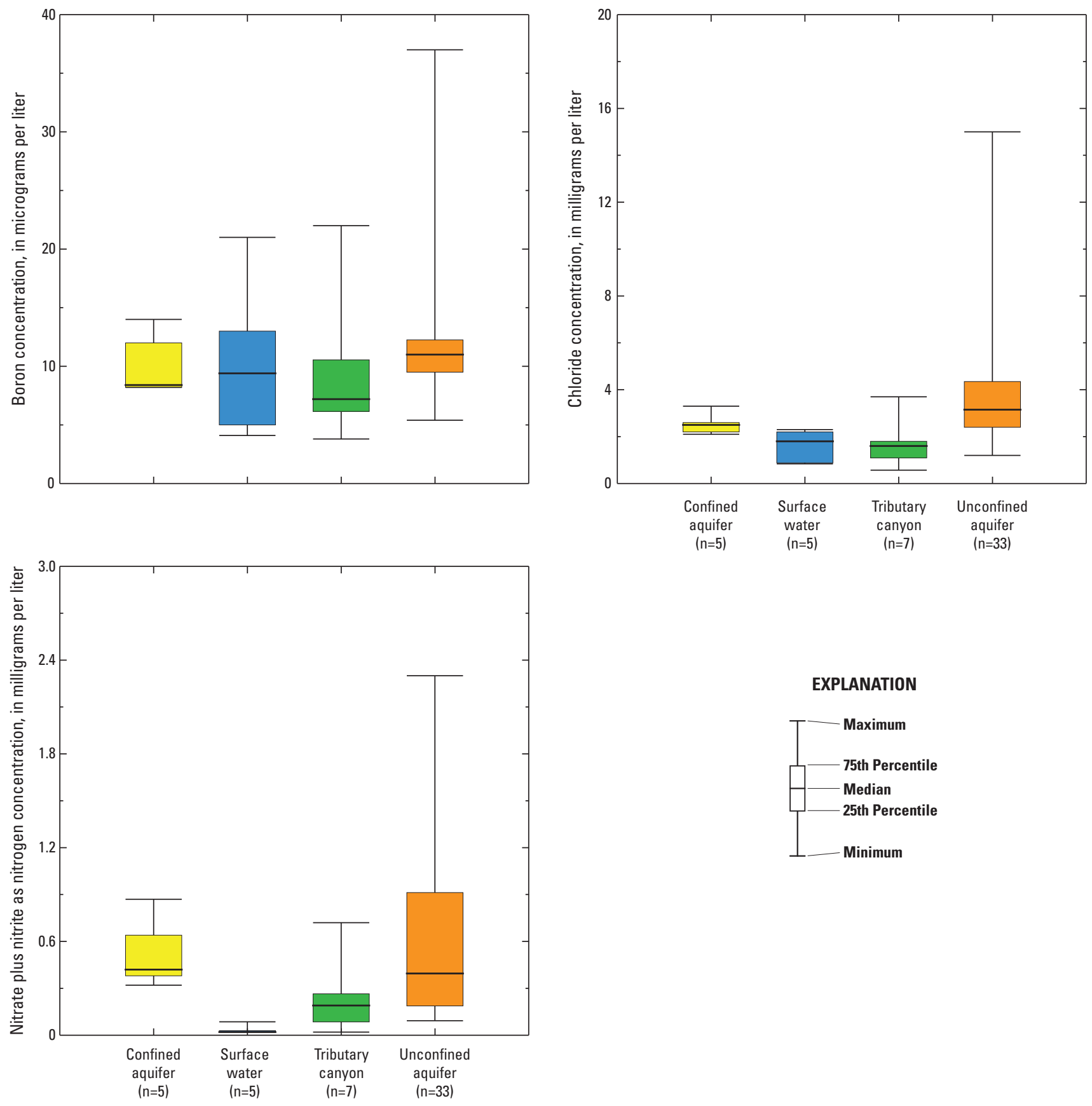

EXPLANATION

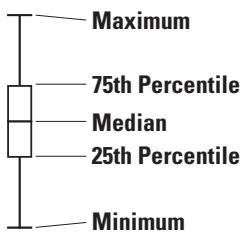

Figure 6. Boron, chloride, and nitrate plus nitrate as nitrogen concentrations in groundwater and surface-water samples, Wood River Valley, south-central Idaho, July and August 2012. Well U30 is not included in this figure due to suspected contamination. 
Table 5. Nutrient concentrations and bacteria counts in groundwater and surface-water samples, Wood River Valley, south-central Idaho, July and August 2012.

[Site locations are shown in figure 2. Values exceeding U.S. Environmental Protection Agency guidelines in bold. Alternate name: C, confined aquifer; SW, surface water; T, bedrock aquifer in tributary canyon; U, unconfined aqufer. A bbreviations: E. coli, Escherichia coli; mg/L, milligram per liter; mL, milliliter; $\mathrm{N}$, nitrogen; P, phosphorous; <, less than; -, no data available]

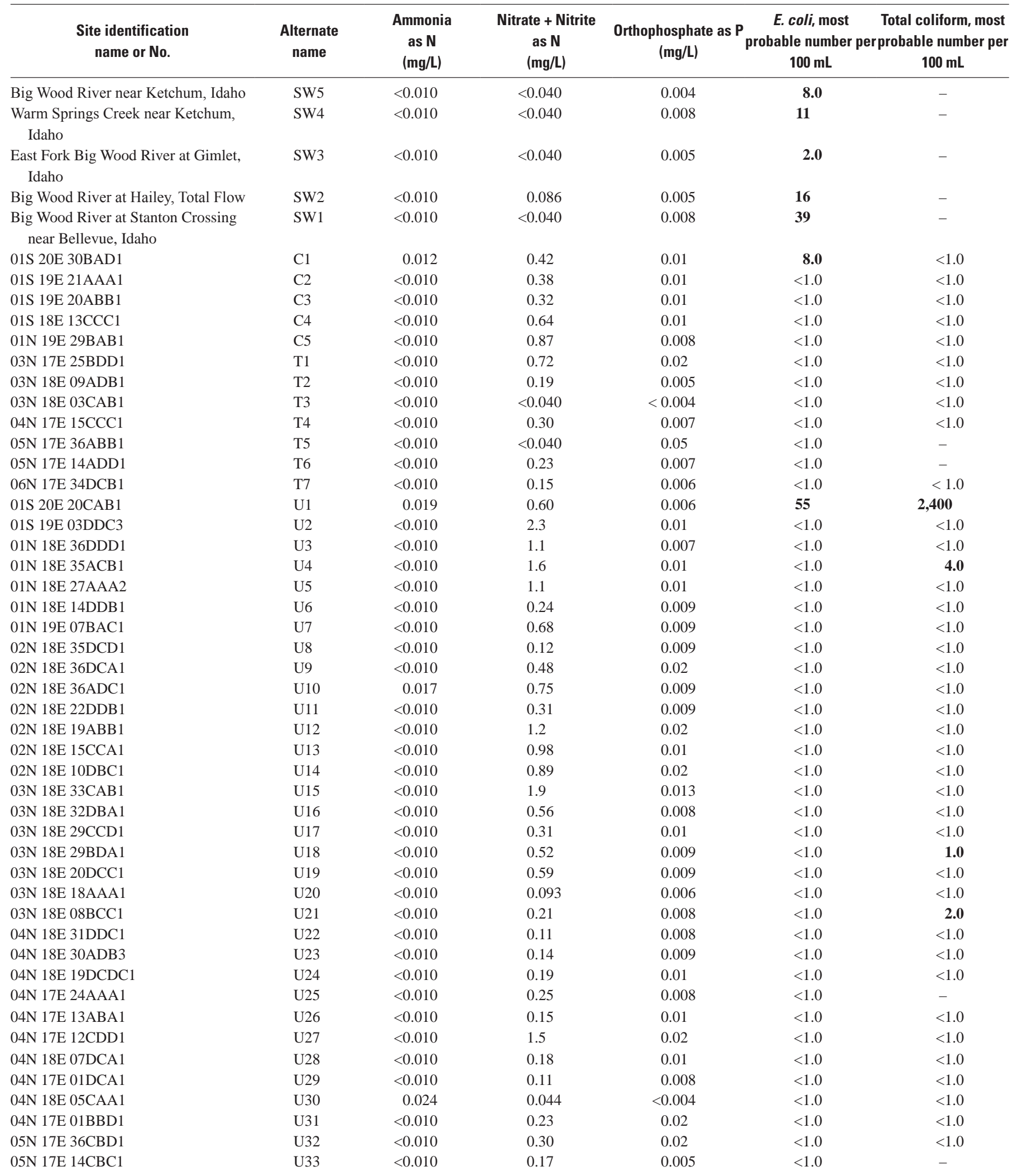




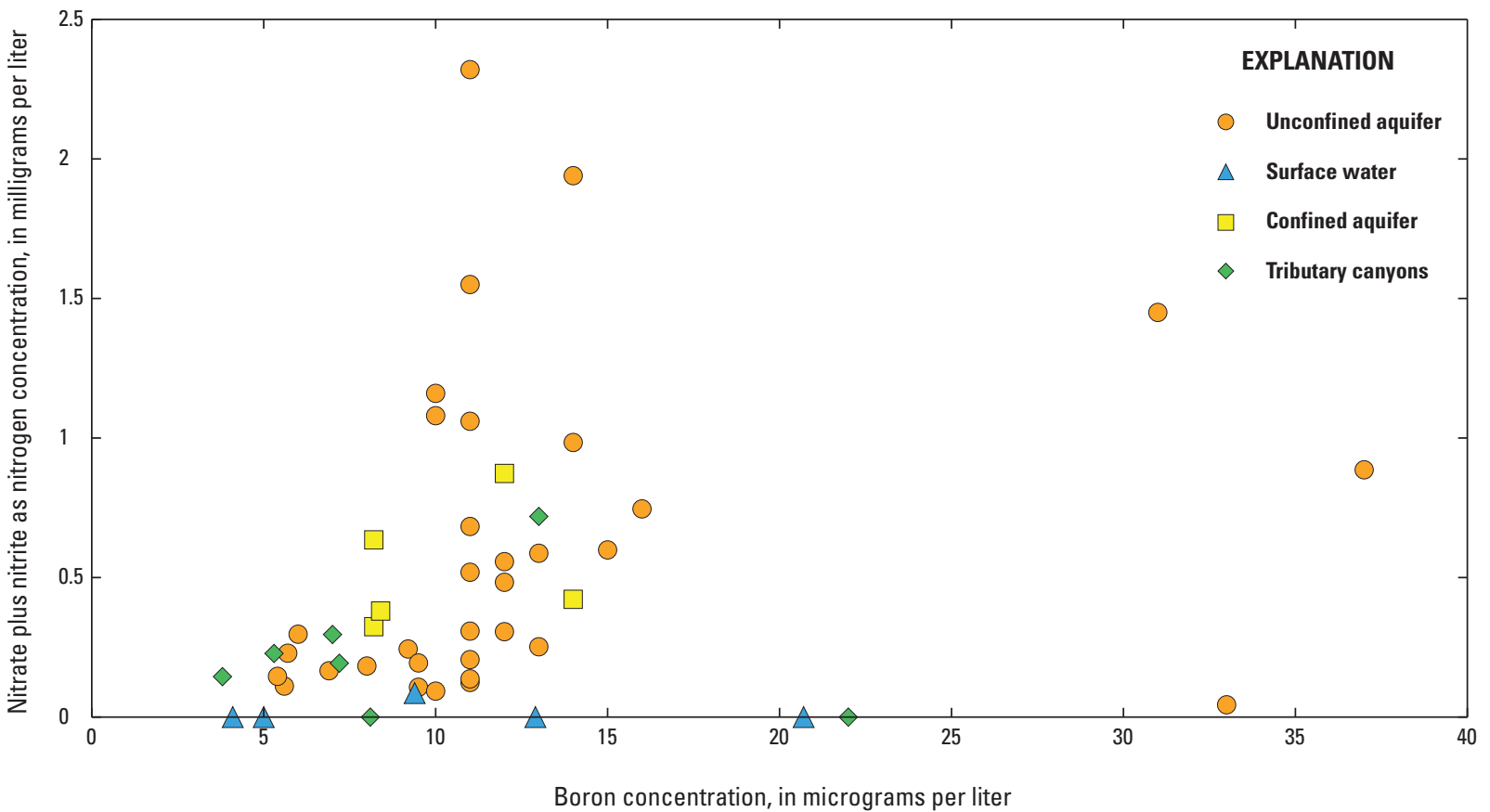

Figure 7. Boron and nitrate plus nitrite as nitrogen concentrations in groundwater and surface water, Wood River Valley, south-central Idaho, July and August 2012.

This pattern of high nitrate plus nitrite and low boron indicates that these higher nutrient concentrations are likely sourced from something other than wastewater from domestic use, such as fertilizers or livestock.

Phosphorus is a common constituent of agricultural fertilizers, manure, detergents, and organic wastes in sewage. Phosphorus in water likely comes from agricultural or domestic fertilizers applied at the land surface, or from wastewater. Concentrations of orthophosphate as phosphorus ranged from less than the detection limit $(0.004 \mathrm{mg} / \mathrm{L})$ to $0.05 \mathrm{mg} / \mathrm{L}$ in groundwater, and from 0.004 to $0.008 \mathrm{mg} / \mathrm{L}$ in surface water. Orthophosphate concentrations did not show a discernible spatial pattern in the study area and concentrations were not elevated near population centers. Castelin and Winner (1975) attributed the relatively low concentrations of orthophosphate in the Wood River Valley to a scarcity of phosphate-bearing minerals in the study area.

Nitrite concentrations from samples were negligible in the study area and were less than the EPA MCL of $1.0 \mathrm{mg} / \mathrm{L}$; nitrogen values are presented as nitrate plus nitrite as nitrogen. Nitrate plus nitrite as nitrogen concentrations greater than $1.0 \mathrm{mg} / \mathrm{L}$ in groundwater (ig. 8) generally were near the population centers of Ketchum and Hailey, and in the Bellevue Fan. The proximity of higher concentrations of nitrate plus nitrite to populated areas suggests an anthropogenic source, such as wastewater or domestic fertilizer application. Nitrate plus nitrite values exceeding $1.0 \mathrm{mg} / \mathrm{L}$ in the Bellevue Fan are generally near agricultural areas, and suggest that these higher values of nitrate may be sourced from fertilizers or livestock. Nitrate plus nitrite values ranged from less than the detection limit $(0.040 \mathrm{mg} / \mathrm{L})$ to $2.3 \mathrm{mg} / \mathrm{L}$ in groundwater, and from below the detection limit to $0.086 \mathrm{mg} / \mathrm{L}$ in surface water (fig. 6). The distribution of nitrate plus nitrite concentrations was similar to that of chloride and boron, suggesting that the large range of nitrate plus nitrite concentrations in the unconfined aquifer is sourced from anthropogenic activities. Low concentrations of nitrate plus nitrite were measured in the confined aquifer, suggesting little influence from anthropogenic activity. Regression analyses of well depth and nitrate concentration in groundwater indicates no relation between the two, confirming the findings of Luttrell and Brockway (1984). Generally, the nitrate concentrations measured during this study were similar to those by Castelin and Winner (1975), Luttrell and Brockway (1984), Schultz (1993), and Brown (2004). Luttrell and Brockway (1984) suggested that nitrate concentrations in groundwater from the Wood River Valley aquifer system likely fluctuates seasonally, although the data from this study could not be used to verify that hypothesis. 


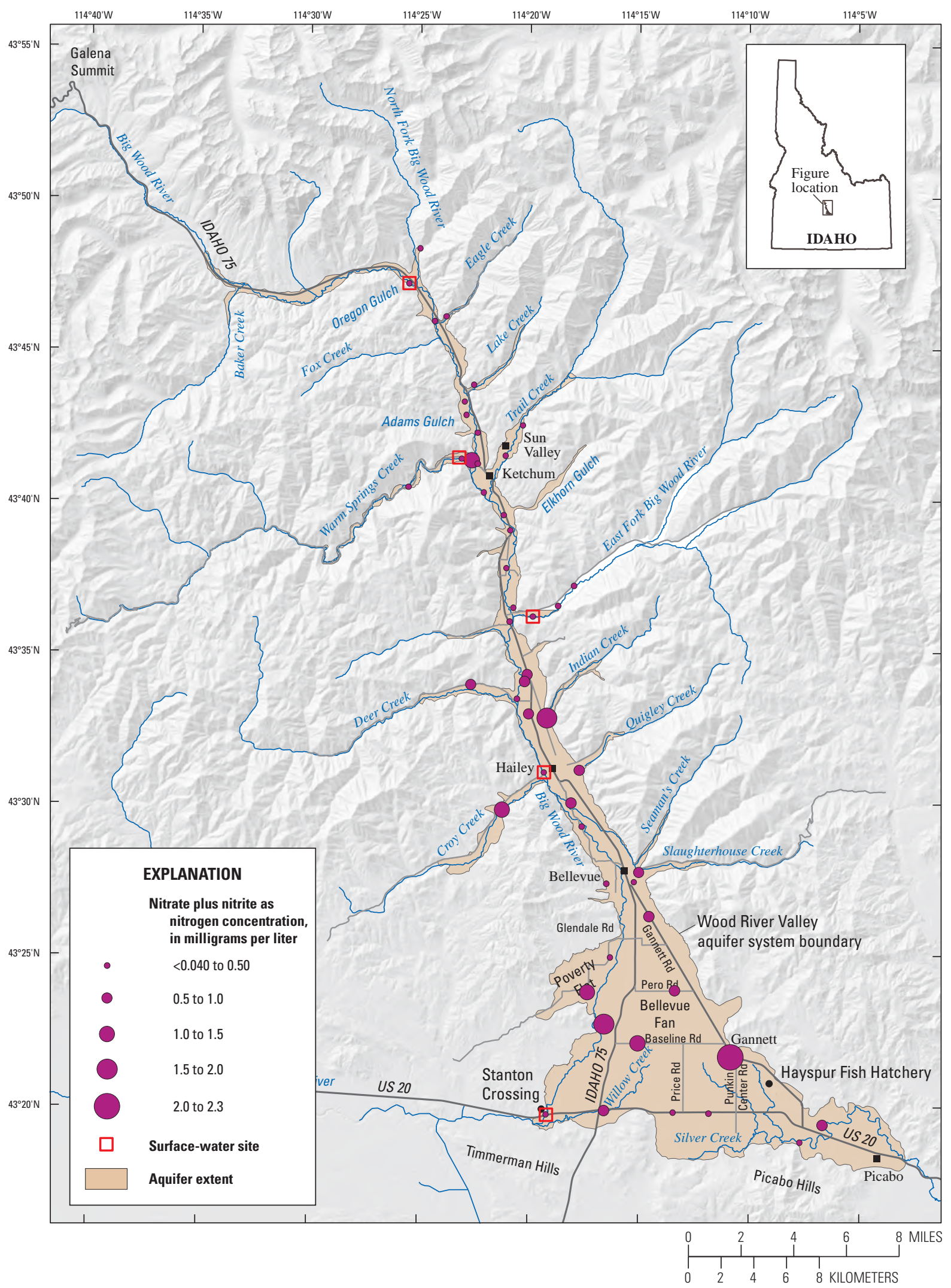

Figure 8. Concentrations of nitrate plus nitrite as nitrogen in groundwater and surface-water samples from the Wood River Valley, south-central Idaho, July and August 2012. 


\section{Total Coliform and Escherichia coli}

Samples were analyzed for E. coli and total coliform bacteria which are both fecal indicator bacteria. Fecal indicator bacteria are used to assess the microbiological quality of water. Although these bacteria are not typically disease causing, they are associated with fecal contamination of the possible presence of waterborne pathogens. The density of indicator bacteria is a measure of water safety for consumption or body-contact recreation.

E. coli (table 5) bacteria were detected in every surfacewater sample, with concentrations ranging from a most probable number of 2 to 39 colony forming units per 100 milliters (CFUs/100 mL). These values are similar to those from previous studies on the Big Wood River (Castelin and Winner, 1975; U.S. Geological Survey, 2013) that indicated E. coli concentations in the Big Wood River ranged from 0 to $156 \mathrm{CFUs} / 100 \mathrm{~mL}$. E. coli concentrations were evaluated with nitrate plus nitrite as an indicator of possible untreated wastewater effluent, confined animal feeding areas, and leaking septic tanks (fig. 9); however, no discernible relation was determined. E.Coli concentrations in the Big Wood River increased in a downstream direction at the time of sampling.

E. coli bacteria were detected in 2 of 45 water samples from wells; total coliform bacteria were detected in 4 of 45 water samples from wells. E. coli bacteria were detected in one sample from the confined aquifer (C1) and in one sample from the unconfined aquifer (U1); both of these wells were near Silver Creek in agricultural areas that may use manure for fertilizer and provide a source of bacteria through this application. Total coliform bacteria were detected in some samples in which E.coli were not detected. Four samples from the unconfined aquifer contained total coliform bacteria (U1, U5, U18, and U21). However, none of the groundwater samples with detectable total coliform bacteria had high nutrient concentrations (fig. 9). The sample from well U1 has a high total coliform count; this is a deep well and the presence of coliform indicates that contamination may have occurred at the surface during sampling. The EPA MCL for any type of coliform (both E. coli and total coliform) is zero in 5 percent or less of all samples tested; the goal for MCL is zero counts in any drinking-water sample.

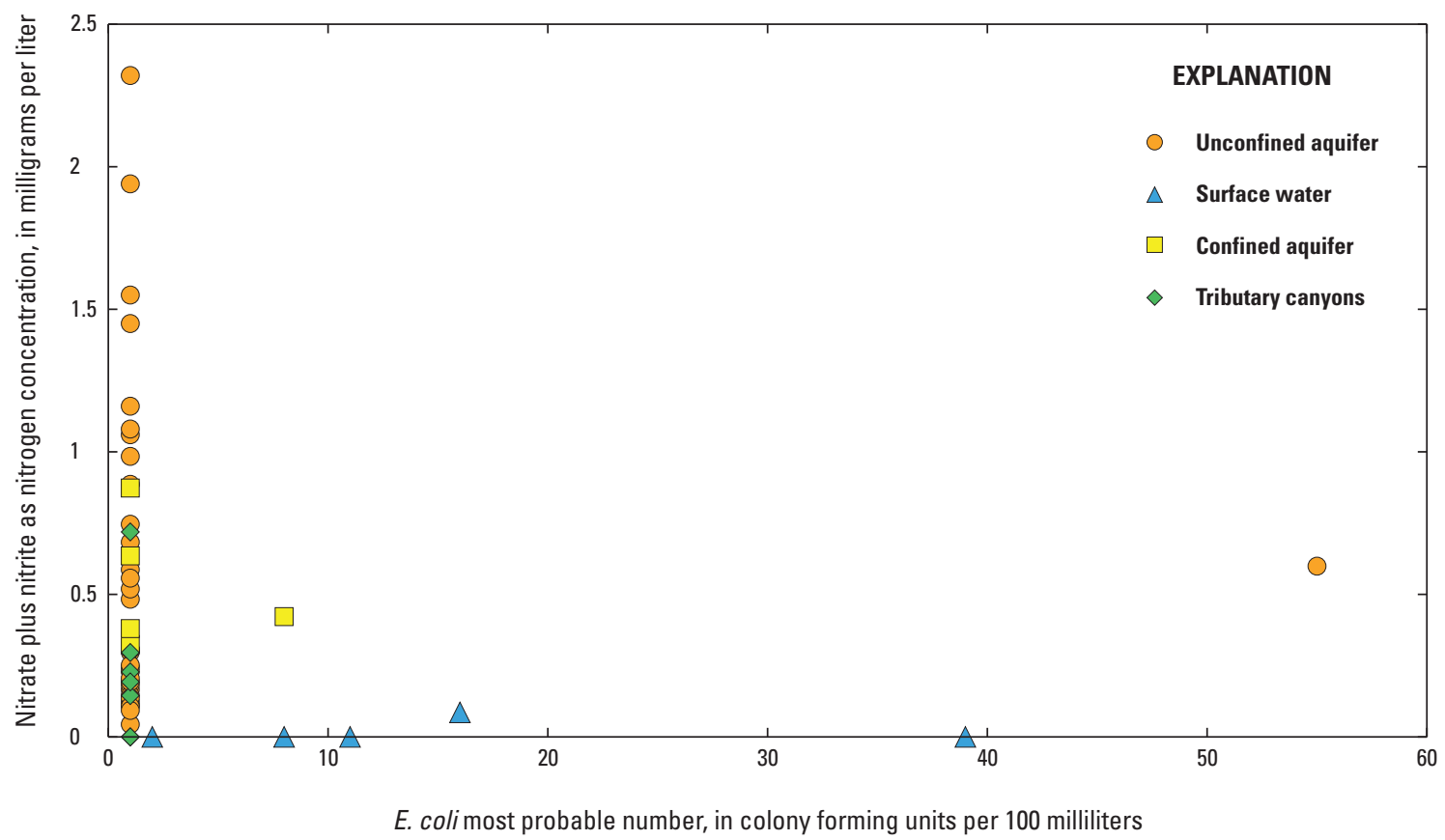

Figure 9. E. coli and nitrate plus nitrate concentrations in groundwater and surface-water samples, Wood River Valley, south-central Idaho, July and August 2012. 


\section{Quality Control Sample Results}

Seven replicate samples and one blank sample were collected to assure consistent quality and lack of contamination in sampling and laboratory methods. One surface-water and six groundwater samples were collected as replicates. Results from the equipment blank and replicate samples are listed in table 6.

The relative percent difference (RPD) between replicate samples was calculated using the formula:

$$
\mathrm{RPD}=\left[\left(\mathrm{V}_{\mathrm{S}}-\mathrm{V}_{\mathrm{R}}\right) /\left(\left(\mathrm{V}_{\mathrm{S}}+\mathrm{V}_{\mathrm{R}}\right) / 2\right)\right] * 100
$$

where

$\mathrm{V}_{\mathrm{S}} \quad$ is the value of one replicate sample, and

$V_{R} \quad$ is the value of the other replicate sample.

Ideally, samples are within a RPD of 10 percent; most analytes met this criterion. However, the RPD for some replicate analyses was greater than 10 percent; the RPDs for chloride, nitrate plus nitrite, orthophosphate, iron, and manganese analyses had at least one set of replicates that exceeded 10 percent (table 6). The concentration values that exceeded a RPD of 10 percent were typically those low concentrations near the reporting limit. Overall, the quality assurance results were considered acceptable for this study.

When the concentration in at least one of the replicates was less than the reporting limit, an RPD could not be calculated. However, if both replicate samples were at concentrations near or less than the reporting limit, the results were considered to be acceptable. For the equipment blank sample, all constituent concentrations were less than laboratory detection limits, indicating the absence of any bias in analytical results which could have resulted from sample contamination in the field or laboratory.

Bacteria samples showed different results in replicates from sites SW1, U18, and T6. Bacteria samples are measured by a counting method after incubation, and colony growth may vary when two samples of the same water are incubated. The most probable number statistical method also may account for variation in the replicate samples. Overall, the bacteria data were considered to be acceptable for the purposes of this report.

\section{Water-Quality Patterns}

Historical water-quality data can be used in conjunction with the data from this study to evaluate temporal changes in water quality in the Wood River Valley. Although time-series plots are not statistical analyses, they show visual patterns in water-quality parameters. Observable patterns in waterquality parameters may provide evidence of natural and (or) anthropogenic effects on the groundwater and surface-water quality in the Wood River Valley.

Time-series plots were generated for chloride and nitrate concentrations in groundwater from six selected wells (fig. 10). Only sites with at least five samples and fewer than 15 years between samples were plotted. Nitrate concentrations in groundwater did not show any obvious long-term upward or downward patterns in the wells examined; all temporal variation in concentration was less than $1.0 \mathrm{mg} / \mathrm{L}$. The small amount of temporal variability in nitrate concentrations indicates a lack of major temporal changes to groundwater inputs. Luttrell and Brockway (1984) reported significant differences in nitrate concentrations in a supply well sampled on different dates in a year and suggested that the population differences between recreational seasons (the "slack" or "shoulder" season) may be the cause.

Chloride concentrations in groundwater exhibited some obvious temporal patterns. Chloride concentrations increased slightly over time in wells U7and 434150114221201; concentrations in wells U13 and U33 exhibited more substantial increases over time. Most of these samples are in the upper valley. Statistical calculations of trends were not performed because there were an insufficient number of samples from the same site collected over time; ideally, a site would have at least twenty values spanning consecutive years for this type of calculation. For future studies to determine trends in concentrations, samples should be collected during the same season for multiple years.

Time-series plots also can be used to evaluate waterquality trends in surface water, although it is difficult because of the influence of fluctuating stream discharge on constituent concentrations. No surface-water sites in appendix B contained enough observations with which to determine statistically valid trends in constituent concentrations. Additional concentration data coupled with streamflow measurements are needed to discern trends in surface-water quality. Ideally, samples would be collected over several years and span the complete range of the stream hydrograph to fully capture variations associated with seasonality and detect trends in concentrations. 

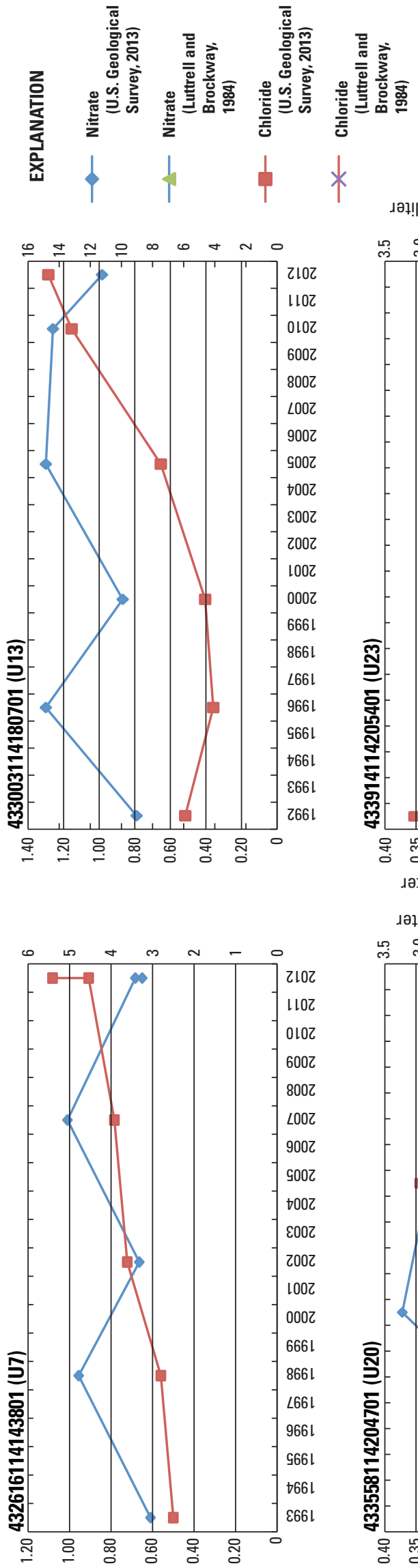

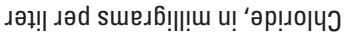

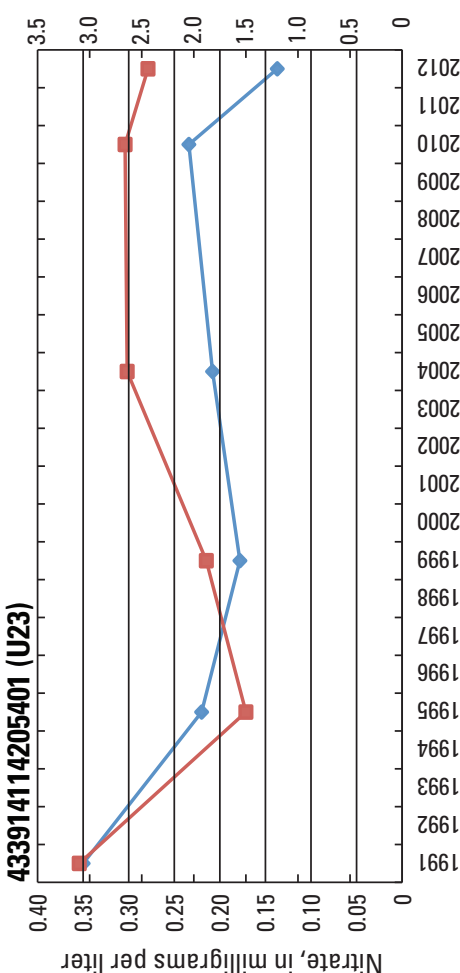

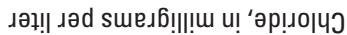
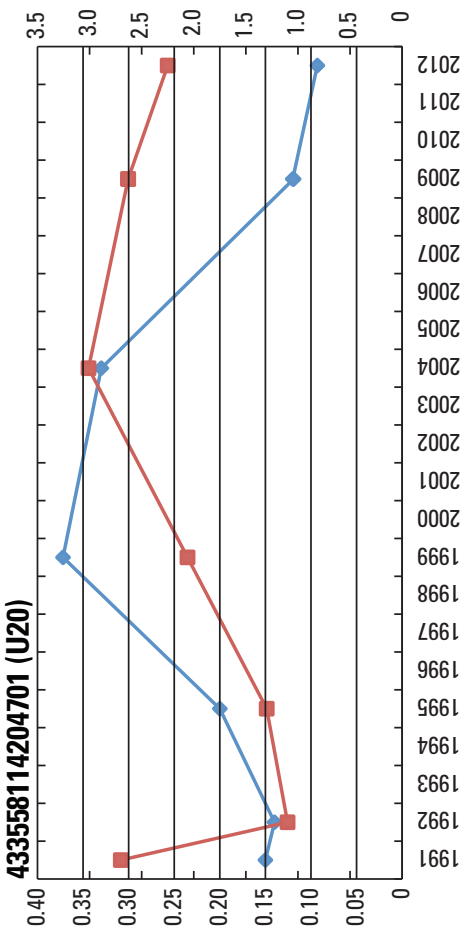

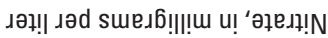

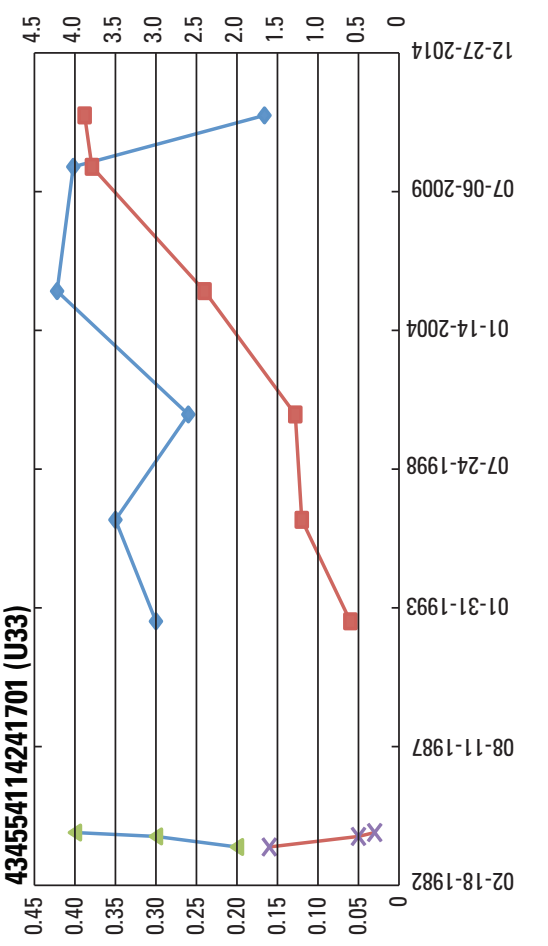

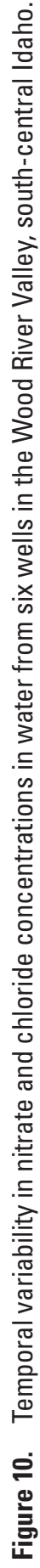


Table 6. Laboratory results for replicate and blank groundwater and surface-water samples, Wood River Valley, south-central Idaho, July and August 2012.

[Site locations are shown in figures 1 and $\underline{3}$. Values in bold are relative percent differences that exceed 10 percent. Alternate name: $\mathrm{C}$, confined aquifer; $\mathrm{SW}$, surface water; T, bedrock aquifer in tributary canyon; U, unconfined aqufer. A bbreviations: E. coli, Escherichia coli; $\mu \mathrm{g} / \mathrm{L}$, microgram per liter; mg/L, milligram per liter; $\mathrm{mL}$, milliliters; $\mathrm{N}$, nitrogen; $\mathrm{P}$, phosphorous; <, less than; -, insufficient data to calculate statistic]

\begin{tabular}{|c|c|c|c|c|c|c|c|c|c|}
\hline $\begin{array}{c}\text { USGS site } \\
\text { identification No. }\end{array}$ & $\begin{array}{c}\text { Ammonia } \\
\text { as N } \\
\text { (mg/L) }\end{array}$ & $\begin{array}{c}\text { Nitrite } \\
\text { as } \mathbf{N} \\
\text { (mg/L) }\end{array}$ & $\begin{array}{c}\text { Nitrate } \\
\text { plus } \\
\text { nitrite } \\
\text { as } \mathrm{N} \\
\text { (mg/L) }\end{array}$ & $\begin{array}{c}\text { Ortho- } \\
\text { phosphate } \\
\text { as P } \\
\text { (mg/L) }\end{array}$ & $\begin{array}{l}\text { Calcium } \\
\text { (mg/L) }\end{array}$ & $\begin{array}{c}\text { Magnesium } \\
\text { (mg/L) }\end{array}$ & $\begin{array}{c}\text { Sodium } \\
\text { (mg/L) }\end{array}$ & $\begin{array}{l}\text { Potassium } \\
\text { (mg/L) }\end{array}$ & $\begin{array}{l}\text { Chloride } \\
\text { (mg/L) }\end{array}$ \\
\hline 13140800 & $<0.010$ & 0.002 & $<0.040$ & 0.008 & 46 & 8.8 & 5.5 & 1.2 & 2.3 \\
\hline 13140800 & $<0.010$ & 0.002 & $<0.040$ & 0.008 & 46 & 8.8 & 5.5 & 1.2 & 2.3 \\
\hline 432351114131701 & $<0.010$ & $<0.001$ & 0.89 & 0.008 & 54 & 12 & 4.8 & 1.0 & 3.3 \\
\hline Relative percent difference between replicates & - & - & 1.7 & 0.0 & 0.2 & 0.8 & 0.2 & 0.0 & 0.6 \\
\hline 432457114161301 & $<0.010$ & $<0.001$ & 0.24 & 0.009 & 37 & 7.1 & 4.6 & 0.93 & 2.1 \\
\hline 432457114161301 & $<0.010$ & 0.001 & 0.23 & 0.009 & 37 & 7.2 & 4.6 & 0.92 & 2.1 \\
\hline 433003114180701 & $<0.010$ & $<0.001$ & 0.97 & 0.011 & 71 & 15 & 7.4 & 1.6 & 15 \\
\hline 433003114180701 & $<0.010$ & $<0.001$ & 0.98 & 0.012 & 70 & 14 & 7.4 & 1.6 & 15 \\
\hline Relative percent difference between replicates & - & - & 1.6 & 8.7 & 1.3 & 1.4 & 0.1 & 0.0 & 0.7 \\
\hline 433359114200901 & $<0.010$ & $<0.001$ & 0.52 & 0.009 & 51 & 14 & 4.5 & 1.2 & 3.2 \\
\hline 433359114200901 & $<0.010$ & $<0.001$ & 0.46 & 0.009 & 51 & 14 & 4.6 & 1.2 & 3.2 \\
\hline Relative percent difference between replicates & - & - & 12.9 & 0.0 & 1.2 & 0.0 & 2.2 & 5.0 & 0.3 \\
\hline 433558114204701 & $<0.010$ & $<0.001$ & 0.11 & 0.007 & 48 & 8.7 & 5.1 & 0.79 & 2.3 \\
\hline 433558114204701 & $<0.010$ & $<0.001$ & 0.093 & 0.006 & 50 & 8.8 & 4.9 & 0.73 & 2.3 \\
\hline Relative percent difference between replicates & - & - & 15.8 & 15.4 & 2.4 & 1.4 & 3.8 & 7.9 & 0.0 \\
\hline
\end{tabular}


Table 6. Laboratory results for replicate and blank groundwater and surface-water samples, Wood River Valley, south-central Idaho, July and August 2012. - Continued

[Site locations are shown in figures 1 and $\underline{3}$. Values in bold are relative percent differences that exceed 10 percent. Alternate name: C, confined aquifer; SW, surface water; T, bedrock aquifer in tributary canyon; U, unconfined aqufer. Abbreviations: E. coli, Escherichia coli; $\mu \mathrm{g} / \mathrm{L}$, microgram per liter; mg/L, milligram per liter; $\mathrm{mL}$, milliliters; N, nitrogen; P, phosphorous; <, less than; -, insufficient data to calculate statistic]

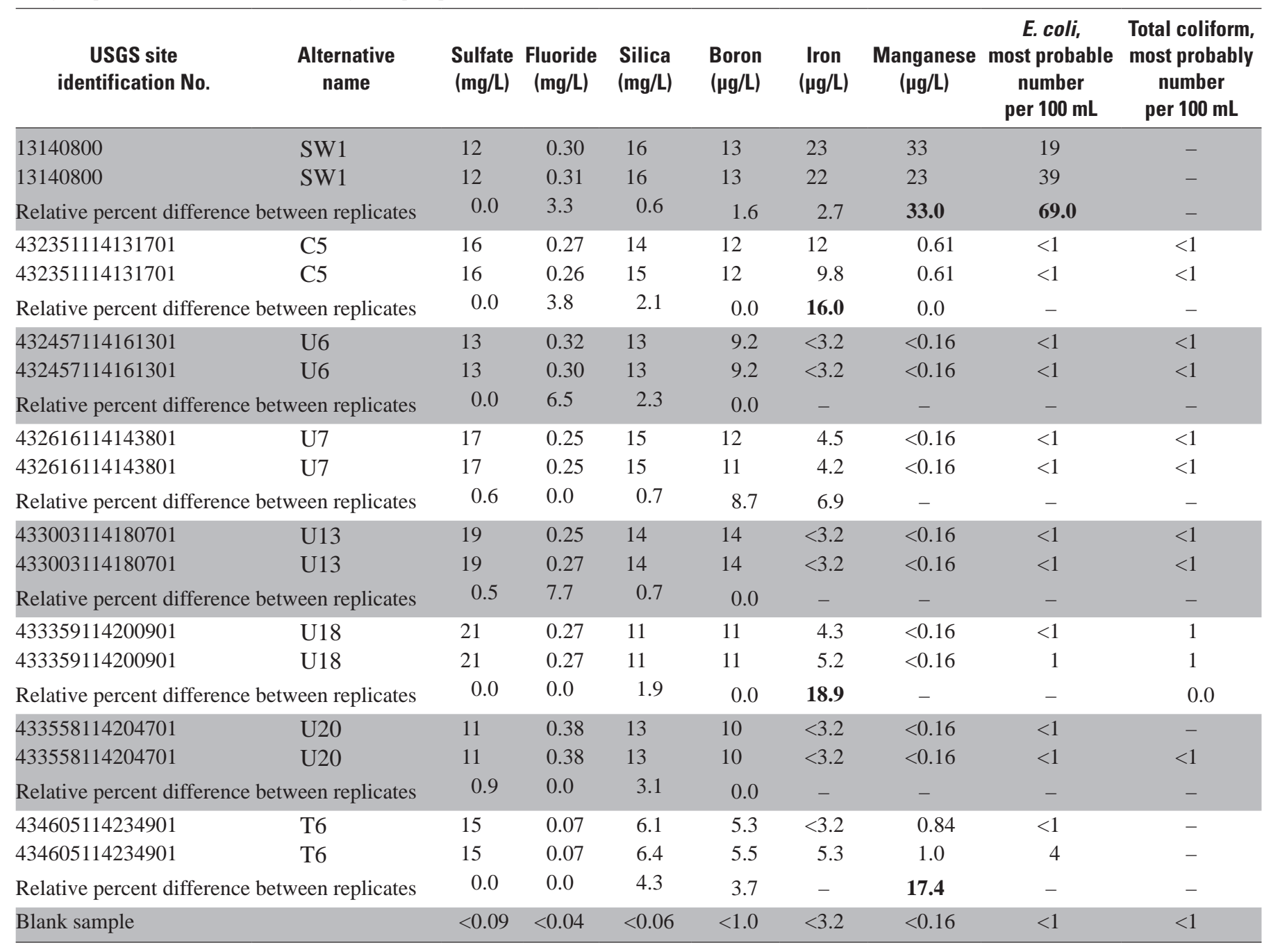




\section{Suggestions for Further Study}

The lack of historical data makes it difficult to determine statistically significant trends in water-quality constituents. Although water-quality data have been collected for many years in the study area, few sites have a sufficient dataset for estimating statistically valid trends. Luttrell and Brockway (1982; 1984), Schultz (1993), and Brown (2002a, 2002b, 2003, and 2004) attempted to determine trends for selected water-quality constituents, but only for short time spans. The establishment of a network of wells and surfacewater sites with seasonal sampling over a number of years would be necessary to provide sufficient data to determine temporal trends. Such a network could be combined with already required regular sampling of public water supplies. Additionally, samples could be collected at one of the established streamgages on the Big Wood River and sampled at least quarterly to integrate water-quality conditions on a basin-wide scale. Ideally, such a site would be located in the reach of the Big Wood River between Bellevue and Glendale Road at a previously-established station to capture trends in surface water in the upper valley.

Anthropogenic contaminants, such as pesticides and pharmaceuticals, were not evaluated in this study; however, anthropogenic contaminants might be present in groundwater and surface water in the Big Wood River Valley because of the presence of septic systems. Other naturally occurring constituents, such as trace metals, were not included in this study and may be elevated in areas with a geologic source. Although mercury has been detected in fish tissue samples collected from Silver Creek (Idaho Department of Health and Welfare, 2013), concentrations were less than consumption standards. Mercury concentrations could be elevated in sport fish, and could be monitored in tissue of fish in the Big Wood River and Silver Creek. Emerging contaminants are a group of compounds that have recently been identified as common in water derived from municipal, agricultural, and industrial sources. These compounds include pharmaceuticals and personal care products (such as cosmetics) that are commonly used in households. Because these compounds are not always effectively treated in wastewater treatment facilities, their presence in wastewater effluent is expected. As the population in the Wood River Valley continues to grow, it will be important to evaluate the potential presence of these compounds in groundwater and surface water.

\section{Summary and Conclusions}

Some residents and resource managers in Blaine County, south-central Idaho, are increasingly concerned about the effects that population growth might have on the quality of groundwater and surface-water supplies. The USGS collected water samples during July and August of 2012 to determine the overall quality of groundwater and surface water in the Wood River Valley. Samples were collected from
45 groundwater sites and 5 surface-water sites distributed throughout the valley to represent bedrock aquifers in tributary canyons, the unconfined aquifer, the confined aquifer, and surface water in the Wood River Valley.

Groundwater and surface-water samples were analyzed for field parameters (temperature, $\mathrm{pH}$, specific conductance, dissolved oxygen, total dissolved solids, and alkalinity), major ions, selected trace elements, nutrients, and E.coli and total coliform bacteria. Sampling occurred during July and August 2012 to minimize variability related to seasonal changes. Most water samples from wells did not exceed EPA standards for drinking-water quality. However, a sample from one well (T3) exceeded the secondary maximum contaminant level for iron, and samples from five wells contained detectable levels of bacteria. All five surface-water samples contained E.coli bacteria, and exceeded the EPA drinking water maximum contaminant level goal for total coliform bacteria.

Most (43 of 50) of the groundwater and surface-water samples collected in the Wood River Valley were a calciummagnesium-bicarbonate type water, indicating that the water chemistry is relatively consistent throughout the study area. Naturally occurring ions and total dissolved solids concentrations tended to be evenly distributed throughout all aquifers, with little variation in concentrations in the confined aquifer. The small variability in chemistry in the confined aquifer suggests this aquifer may be isolated from anthropogenic activity or contain old, isolated water.

Generally, nutrient concentrations were low throughout the Wood River Valley. Nitrate plus nitrite concentrations tended to be higher near population centers and agricultural areas, suggesting an anthropogenic source of nitrate to groundwater. Nitrate and nitrite concentrations were less than EPA drinking water standards in every sample collected. Several groundwater and surface-water samples contained E.coli and total coliform bacteria; E.coli was detected in all surface-water samples and in two groundwater samples. Chloride, boron, and nitrate plus nitrite concentrations displayed a different distribution pattern throughout aquifers, with greater variability in concentrations in the unconfined aquifer than other aquifers. This pattern of wide concentration ranges throughout the unconfined aquifer suggests an anthropogenic source of chloride, boron, and nitrate plus nitrite to groundwater.

Due to the limited amount of comparable data at individual sites and to seasonal variations in constituent concentrations, long-term statistical trends in water-quality constituents could not be analyzed. A visual inspection of historical data shows increasing chloride concentrations and steady nitrate concentrations, but this pattern was not statistically confirmed. Future efforts to identify trends in specific water-quality constituents would require regular monitoring at consistent locations and at specific times of the year. A consistent sampling approach over a number of years would be necessary to identify changes in water-quality conditions over time, and as the population in the Wood River Valley continues to grow. 


\section{Acknowledgments}

The authors wish to thank the owners of the wells sampled in this study for their time and assistance. For their assistance during the preparation of this report, we thank Robert Erickson of the South Central Health District, Patrick McMahon of Sun Valley Water and Sewer District, and David Rambo of the City of Ketchum. Technical and field assistance was provided by James Schaefer, Dorene MacCoy, and Annette Campbell of the USGS. We gratefully acknowledge the assistance and support provided by the Blaine County Commissioners (2012-13): Tom Bowman, Jacob Greenberg, Angenie McCleary, and Lawrence Schoen. Funding and technical assistance was provided by Blaine County, the City of Hailey, the City of Ketchum, The Nature Conservancy, the City of Sun Valley, the Sun Valley Water and Sewer District, the Blaine Soil Conservation District, and the City of Bellevue. Finally, we thank all of the citizens of the Wood River Valley who funded and supported this work.

\section{References Cited}

Anderson, J.E., and Bideganeta, Kim, 1985, A preliminary geologic reconnaissance of the geothermal occurrences of the Wood River drainage area: Idaho Department of Water Resources Water Information Bulletin 30, Part 13, Geothermal Investigations in Idaho, 49 p., accessed July 7, 2013, at http://www.idwr.idaho.gov/WaterInformation/ Publications/wib/wib30p13-geothermal_wood_river_ drainage area.pdf.

Bartolino, J.R., 2009, Ground-water budget for the Wood River Valley aquifer system, south-central Idaho: U.S. Geological Survey Scientific Investigations Report 2009-5016, 36 p. (Also available at http://pubs.usgs.gov/ $\underline{\operatorname{sir} / 2009 / 5016 / .)}$

Bartolino, J.R., and Adkins, C.B., 2012, Hydrogeologic framework of the Wood River Valley aquifer system, south-central Idaho: U.S. Geological Survey Scientific Investigations Report 2012-5053, 46 p., 1 pl. (Also available at http://pubs.usgs.gov/sir/2012/5053/.)

Brown, A.L., Jr., 2002a, Report on water quality data, and research activity in Blaine County, Idaho: Ketchum, Idaho, prepared by Water Resources Consulting for Blaine County Board of Commissioners, January 21, 2002, revised February 18, 2002, 34 p., accessed October 23, 2012, at http://savesilvercreek.com/Pdf_files/Brown_2002.pdf.

Brown, A.L., Jr., 2002b, Blaine County groundwater quality monitoring network: Ketchum, Idaho, prepared by Water Resources Consulting for Blaine County Board of Commissioners, September 24, 2002, project 467427, 22 p. plus table.
Brown, A.L., Jr., 2003, Blaine County groundwater quality monitoring network: Ketchum, Idaho, prepared by Water Resources Consulting for Blaine County Board of Commissioners, September 22, 2003, project 467427, 16 p. plus tables.

Brown, A.L., Jr., 2004, Blaine County groundwater quality monitoring network: Ketchum, Idaho, prepared by Water Resources Consulting for Blaine County Board of Commissioners, September 30, 2004, project 467427, variously paged plus tables.

Buhidar, B.B., 2002, The Big Wood River Watershed Management Plan: Twin Falls, Idaho Department of Environmental Quality, 177 p., accessed October 23, 2012, at http://www.deq.idaho.gov/media/450316- water data reports_surface_water_tmdls_big_wood_river_big_wood entire.pdf.

Burkett, G.R., and Litke, R.T., 1989, Warm Springs Creek geothermal study, Blaine County, Idaho: Boise, Idaho Department of Health and Welfare, Division of Environmental Quality, Water Quality Status Report No. 84, 76 p., accessed October 23, 2012, at http://www.deq.idaho. gov/media/436399-wqs84 warm springs ck 1987.pdf.

Castelin, P.M., and Chapman, S.L., 1972, Water resources of the Big Wood River-Silver Creek area, Blaine County, Idaho: Boise, Idaho Department of Water Administration, Water Information Bulletin 28, 44 p., accessed August 8, 2013, at http://www.idwr.idaho.gov/WaterInformation/ Publications/wib/wib28-big wood river-silver creek area. pdf.

Castelin, P.M., and Winner, J.E., 1975, Effects of urbanization on the water resources of the Sun Valley-Ketchum area, Blaine County, Idaho: Boise, Idaho Department of Water Resources, Water Information Bulletin 40, 86 p., accessed August 8, 2013, at http://www.idwr.idaho.gov/ WaterInformation/Publications/wib/wib40-sun valleyketchum area.pdf.

CH2M-Hill, 1986, Field investigation and resource evaluation for the Guyer Hot Springs geothermal area: Sun Valley, Idaho, report prepared for Pesch and Co., 26 p.

Connolly, J.B., Lopez-Bernal, K.E., and Shaffer, D.L., 2003, Blaine County evaluation and assessment of nitrogen sources: Massachusetts Institute of Technology, project report for Blaine County Board of Commissioners, 225 p., accessed October 17, 2012, at http://waterdeva.com/pdfs/ Connolly et al 2003.pdf.

Cunningham, W.L., and Schalk, C.W., comps., 2011, Groundwater technical procedures of the U.S. Geological Survey: U.S. Geological Survey Techniques and Methods, book 1, chap. A1, 151 p. (Also available at http://pubs.usgs. gov/tm/1a1/.) 
Davidson, M., and Brown, A.L., Jr., 2002, Summary of ecological profile for Silver Creek Idaho: Letter dated August 13, 2002, 9 p., accessed February 28, 2013, at: http://www.savesilvercreek.org/written docs master list. $\underline{\mathrm{htm}}$.

DesVoigne, D., Capestany, G., and Wallick, L., 1976, An evaluation of the influence of the Ketchum sewage treatment plant upon the Big Wood River: Parametrix Incorporated, final report, 38 p. plus appendices.

Ecosystem Sciences Foundation, 2012, 2011 Silver Creek Annual Report: Boise, Idaho, Ecosystem Sciences Foundation report for the Silver Creek Alliance, 16 p., accessed October 17, 2012, at http://www.savesilvercreek. org/written docs master list.htm.

Eldridge, G.H., 1896, A geological reconnaissance across Idaho, in Walcott, C.D., Sixteenth Annual Report of the United States Geological Survey to the Secretary of the Interior, 1894-1895-Part 2: U.S. Geological Survey Annual Report, p. 217-282. (Also available at http://pubs. er.usgs.gov/pubs/ar/ar16 2.)

Fishman, M.J., and Friedman, L.C., 1989, Methods for determination of inorganic substances in water and fluvial sediments: U.S. Geological Survey Techniques of Water Resources Investigations, book 5, chap. A1, 545 p.

Forstall, Richard, ed., 1995, Idaho population of counties by decennial census-1900 to 1990: U.S. Bureau of the Census, accessed January 31, 2012, at http://www.census. gov/population/cencounts/id190090.txt.

Frenzel, S.A., 1989, Water resources of the upper Big Wood River basin, Idaho: U.S. Geological Survey WaterResources Investigations Report 89-4018, 47 p. (Also available at http://pubs.er.usgs.gov/pubs/wri/wri894018.)

Hauck, F.R., 1947, Preliminary observations on Silver Creek and it's headwater tributaries with notes on population studies and some fishing results: Boise, Idaho Fish and Game Department, 8 p., accessed October 17, 2012, at http://www.savesilvercreek.org/written docs master list. $\underline{\mathrm{htm}}$.

Idaho Department of Environmental Quality, 2011, Errata to the Big Wood River Watershed Management Plan (TMDL) of 2002: Boise, Idaho Department of Environmental Quality, 8 p., accessed October 23, 2012, at http://www.deq. idaho.gov/media/757583-big-wood-river-tmdl-errata-1111. pdf.

Idaho Department of Health and Welfare, 2013, The Idaho Fish Consumption Advisory Program: Boise, Idaho Department of Health and Welfare, accessed March 4, 2013, at http://www.healthandwelfare.idaho.gov/Health/ EnvironmentalHealth/FishAdvisories/tabid/180/Default. aspx.
Jones, R.P., 1952, Evaluation of streamflow records in the Big Wood River basin, Blaine County, Idaho: U.S. Geological Survey Circular 192, 59 p., 1 pl. (Also available at http:// pubs.er.usgs.gov/usgspubs/cir/cir192.)

Lindgren, Waldemar, 1900, The gold and silver veins of Silver City, De Lemar, and other mining districts in Idaho, in Walcott, C.D., Twentieth Annual Report of the United States Geological Survey to the Secretary of the Interior, 1894-1895-Part III—Precious-metal mining districts: U.S. Geological Survey Twentieth Annual Report, Part 3, p. 75-256. (Also available at: http://pubs.er.usgs.gov/ publication/ar20 3.)

Luttrell, S.P., and Brockway, C.E., 1982, Impacts of individual on-site sewage disposal facilities on mountain valleysPhase I: Moscow, University of Idaho, Idaho Water and Energy Resources Research Institute, Research Technical Completion Report A-084-IDA, 52 p.

Luttrell, S.P., and Brockway, C.E., 1984, Impacts of individual on-site sewage disposal facilities on mountain valleys-Phase II-Water-quality considerations: Moscow, University of Idaho, Idaho Water and Energy Resources Research Institute, Research Technical Completion Report WRIP/371403, $74 \mathrm{p}$.

Malcolm, M.J., and Smith, C.L., 1991, Analytical results and sample locality maps of USGS and NURE samples from the Hailey 1 degree $\times 2$ degrees Quadrangle, Idaho: U.S. Geological Survey Open-File Report 92-24, 268 p. (Also available at http://pubs.er.usgs.gov/pubs/ofr/ofr9224.)

Manuel, C.Y., Minshall, G.W., and Bruns, D.A., 1978, Effects of nitrogenous wastes on aquatic plant growth in the Big Wood River, Idaho: U.S. Army Corps of Engineers, Walla Walla District, 84 p. plus appendix.

McIntyre, D.H., ed., 1985, Symposium on the geology and mineral deposits of the Challis 1 degree by 2 degree quadrangle, Idaho: U.S. Geological Survey Bulletin 1658 A-S, 227 p. (Also available at http://pubs.er.usgs.gov/ publication/b1658AS.)

Minshall, G.W., 1977, A literature search to determine the base-line conditions and effects of pollution on the Big Wood River and Magic Reservoir, Idaho: U.S. Army Corps of Engineers, Walla Walla District, 24 p.

Mitchell, J.C., 1986, Stable isotope investigations of selected thermal and nonthermal waters in the Big Wood River drainage area, in Anderson, J.E., and Bideganeta, K., 1985, Geothermal investigations in Idaho, part 13, A preliminary geologic reconnaissance of the geothermal occurrences of the Wood River drainage area: Boise, Idaho Department of Water Resources Water Information Bulletin 30, Part 13, p. 38-46, accessed August 8, 2013, at http://www.idwr. idaho.gov/WaterInformation/Publications/wib/wib30p13geothermal wood river drainage area.pdf. 
National Climatic Data Center, 2012, Historical Palmer drought indices: National Oceanic and Atmospherica Administration database, accessed October 17, 2012, at http://www.ncdc.noaa.gov/temp-and-precip/drought/ historical-palmers.php.

Pentzer, Chuck, 2006, The Big Wood River watershed Total Maximum Daily Load (TMDL)_Implementation plan for agriculture: Prepared by Idaho Soil Conservation Commission for Idaho Department of Environmental Quality, 68 p., accessed October 23, 2012, at http://www. deq.idaho.gov/media/450319- water data reports surface water tmdls big wood river big wood ag imp plan.pdf.

Piper, A.M., 1944, A graphic procedure in the geochemical interpretation of water analyses: Transactions, American Geophysical Union, v. 25, p. 914-923.

Renk, Russ, 1986, Impacts of geothermal waters on selected streams in southern Idaho: Boise, Idaho Department of Health and Welfare, Division of Environment, Water Quality Status Report No. 60, 13 p., plus 2 appendixes, accessed October 23, 2012, at http://www.deq.idaho.gov/ media/435172-wqs60 geothermal waters 1986.pdf.

Schultz, T.S., 1993, Assessing the impacts of on-site sewage systems on groundwater quality Blaine County, Idaho: Seattle, University of Washington, M.P.H. thesis, 72 p.

Skinner, K.D., Bartolino, J.R., and Tranmer, A.W., 2007, Water-resource trends and comparisons between partial development and October 2006 hydrologic conditions, Wood River Valley, south-central Idaho: U.S. Geological Survey Scientific Investigations Report 2007-5258, 31 p., 4 pls., 1 appendix. (Also available at http://pubs.usgs.gov/ sir/2007/5258/.)

Smith, R.O., 1959, Ground-water resources of the middle Big Wood River-Silver Creek area, Blaine County, Idaho: U.S. Geological Survey Water-Supply Paper 1478, 61 p., 2 pls. (Also available at http://pubs.er.usgs.gov/usgspubs/wsp/ wsp1478.)

Spence, C.C., 1999, For Wood River or bust-Idaho’s silver boom of the 1880s: Moscow, Idaho, University of Idaho Press, 260 p.

Street, L.V., 1990, Geothermal investigations in IdahoGeothermal resource analysis in the Big Wood River Valley, Blaine County, Idaho: Boise, Idaho Department of Water Resources Water Information Bulletin 30, part 17, 26 p., accessed August 8, 2013, at http://www.idwr.idaho.gov/ WaterInformation/Publications/wib/wib30p17-geothermal big wood river valley.pdf.
Turnipseed, D.P., and Sauer, V.B., 2010, Discharge measurements at gaging stations: U.S. Geological Survey Techniques and Methods, book 3, chap. A8, 87 p. (Also available at http://pubs.usgs.gov/tm/tm3-a8/.)

Umpleby, J.B., Westgate, L.G., Ross, C.P., and Hewett, D.F., 1930, Geology and ore deposits of the Wood River region, Idaho, with a description of the Minnie Moore and near-by mines: U.S. Geological Survey Bulletin 814, 250 p. (Also available at http://pubs.usgs.gov/bul/0814/report.pdf.)

U.S. Census Bureau, 2011, State and county Quickfacts, Blaine County, Idaho: U.S. Census Bureau database, accessed August 5, 2011, at http://quickfacts.census.gov/ qfd/states/16/16013.html.

U.S. Environmental Protection Agency, 2005, Minnie Moore Mine Pollution Report 3: U.S. Environmental Protection Agency, accessed October 17, 2012, at http://www.epaosc. org/site/polrep_profile.aspx?site_id=1896.

U.S. Environmental Protection Agency, 2007, Triumph Mine tailings piles, Idaho: U.S. Environmental Protection Agency, updated February 2007, accessed October 17, 2012, at http://yosemite.epa.gov/r10/nplpad.nsf/8f2c285be1a7a1fa88 2568db00688860/18bead6a3f7e283485256595005342b1?O penDocument.

U.S. Environmental Protection Agency, 2012, Drinking water contaminants, National Primary Drinking Water Regulations and National Secondary Drinking Water Regulations: U.S. Environmental Protection Agency Web site, accessed October 17, 2012, at http://water.epa.gov/ drink/contaminants/index.cfm.

U.S. Geological Survey, variously dated, National field manual for the collection of water-quality data: U.S. Geological Survey Techniques of Water-Resources Investigations, book 9, chaps. A1-A9, variously paged. (Also available at http://water.usgs.gov/owq/FieldManual/.)

U.S. Geological Survey, 2013, National Water Information System, Idaho: U.S. Geological Survey database, accessed July 22, 2013, at http://waterdata.usgs.gov/id/nwis/nwis.

Winkler, G.R., Soulliere, S.J., Worl, R.G., and Johnson, K.M., eds., 1989, Geology and mineral deposits of the Hailey and western Idaho Falls 1 degree $\times 2$ degrees quadrangles, Idaho: U.S. Geological Survey Open-File Report 89-639, 140 p. (Also available at http://pubs.er.usgs.gov/publication/ ofr89639.)

Wolter, Mike., Todd, Paul, and Watters, Ed, 1994, Silver Creek Preserve stream quality monitoring summary, 1991-1994: Picabo, Idaho, The Nature Conservancy, 12 p., accessed October 17, 2012, at http://www.savesilvercreek.org/ written docs master list.htm. 
Worl, R.G., and Johnson, K.M., 1995, Map showing geologic terranes of the Hailey 1 degree $\times 2$ degrees quadrangle and the western part of the Idaho Falls 1 degree $\times 2$ degrees quadrangle, south-central Idaho: U.S. Geological Survey Bulletin 2064-A, 1 pl., scale 1:250,000. (Also available at http://pubs.usgs.gov/bul/b2064-a/.)
Worl, R.G., Link, P.K., Winkler, G.R., and Johnson, K.M., eds., 1995, Geology and mineral resources of the Hailey 1 degree by 2 degrees quadrangle and the western part of the Idaho Falls 1 degree $\times 2$ degrees quadrangle, Idaho: U.S. Geological Survey Bulletin 2064-A-R, variously paged, 2 pls. (Also available at http://pubs.er.usgs.gov/publication/ b2064AR.) 


\section{Appendixes}

Appendix tables are presented as Microsoft ${ }^{\circledR}$ Excel spreadsheets and can be downloaded at http://pubs.usgs.gov/ sir/2013/5163/.

Appendix A. Historical Groundwater Water-Quality Data from the Wood River Valley, South-Central Idaho

Appendix B. Historical Surface-Water Quality Data from the Wood River Valley, South-Central Idaho 
Publishing support provided by the U.S. Geological Survey Publishing Network, Tacoma Publishing Service Center

For more information concerning the research in this report, contact the Director, Idaho Water Science Center

U.S. Geological Survey

230 Collins Road

Boise, Idaho 83702

http://id.water.usgs.gov

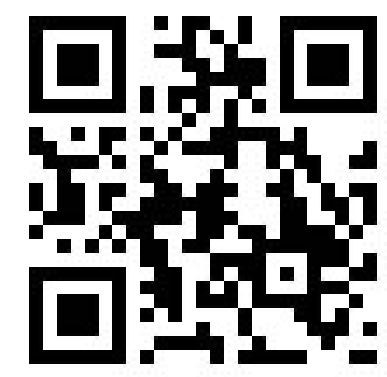




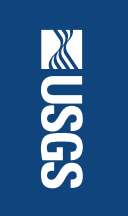

동

亏ัँ

맘

잏

을

음

몸

$\sum_{0}^{\circ}$

क्ञ

言

高

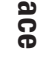

蛋

응

꽁

音

琼

os

ब.

言

离

$\stackrel{\infty}{\circ}$

을

홍

ग 